\title{
A new genus and two new species of cave-dwelling cyclopoids (Crustacea, Copepoda) from the epikarst zone of Thailand and up-to-date keys to genera and subgenera of the Bryocyclops and Microcyclops groups
}

\author{
Chaichat BOONYANUSITH ${ }^{1}$, La-orsri SANOAMUANG ${ }^{2}$ \& Anton BRANCELJ ${ }^{3, *}$ \\ ${ }^{1}$ School of Biology, Faculty of Science and Technology, Nakhon Ratchasima Rajabhat University, 30000, Thailand. \\ ${ }^{2}$ Applied Taxonomic Research Centre, Faculty of Science, Khon Kaen University, \\ Khon Kaen, 40002, Thailand. \\ ${ }^{2}$ Faculty of Science, Mahasarakham University, Maha Sarakham, 44150, Thailand. \\ ${ }^{3}$ National Institute of Biology,Večna pot 111, SI-1000 Ljubljana, Slovenia. \\ ${ }^{3}$ School of Environmental Sciences, University of Nova Gorica, Vipavska c. 13, 5000 Nova Gorica, Slovenia. \\ ${ }^{*}$ Corresponding author: anton.brancelj@nib.si \\ ${ }^{1}$ Email: chaichat2010@yahoo.com \\ ${ }^{2}$ Email: 10icoc@gmail.com \\ ${ }^{1}$ urn:1sid:zoobank.org:author:5290B3B5-D3B3-4CF2-AF3B-DCEAEAE7B51D \\ ${ }^{2}$ urn:lsid:zoobank.org:author:F0CBCDC7-64C8-476D-83A1-4F7DB7D9E14F \\ ${ }^{3}$ urn:lsid:zoobank.org:author:CE8F02CA-A0CC-4769-95D9-DCB1BA25948D
}

\begin{abstract}
Two obligate cave-dwelling species of cyclopoid copepods (Copepoda, Cyclopoida) were discovered inside caves in central Thailand. Siamcyclops cavernicolus gen. et sp. nov. was recognised as a member of a new genus. It resembles Bryocyclops jankowskajae Monchenko, 1972 from Uzbekistan (part of the former USSR). It differs from it by (1) lack of pointed triangular prominences on the intercoxal sclerite of the fourth swimming leg, (2) mandibular palp with three setae, (3) spine and setal formulae of swimming legs 3.3.3.2 and 5.5.5.5, respectively, and (4) specific shape of spermatophore. Metacyclops thailandicus sp. nov. resembles M. cushae Reid, 1991 from Louisiana (USA). It differs from it by (1) distal segment of the endopod of the fourth swimming leg with one apical spine, (2) the fifth swimming legs with one broad segment, (3) the spine formula of the distal segment of the exopod of the swimming legs 3.4.3.3, and (4) well developed anal operculum reaching articulation with caudal rami. Detailed descriptions of the habitats of the new species and up-to-date keys to the genera and subgenera of the Bryocyclops and Microcyclops groups are provided, along with an updated list of obligate groundwater species of Copepoda in Southeast Asia.
\end{abstract}

Keywords. Siamcyclops cavernicolus gen. et sp. nov., Metacyclops thailandicus sp. nov., stygobionts, groundwater environment, epikarstic drip.

Boonyanusith C., Sanoamuang L. \& Brancelj A. 2018. A new genus and two new species of cave-dwelling cyclopoids (Crustacea, Copepoda) from the epikarst zone of Thailand and up-to-date keys to genera and subgenera of the Bryocyclops and Microcyclops groups. European Journal of Taxonomy 431: 1-30. https://doi.org/10.5852/ejt.2018.431 


\section{Introduction}

Current knowledge of freshwater cyclopoid copepods in Thailand and neighbouring countries is still insufficient. Most studies are based exclusively on epigean fauna (Bricker et al. 1978; Boonsom 1984; Lim \& Fernando 1985; Sanoamuang 1999; Alekseev \& Sanoamuang 2006; Chaichareon et al. 2011). The most recent list of freshwater Cyclopoida from Thailand contains 45 taxa, most of them with Afroand Indo-Eurasian distributions (Alekseev \& Sanoamuang 2006). However, this total number may be underestimated. Recently, two new cyclopoid species from Thailand were described, Afrocyclops henrii from freshwater (Alekseev \& Sanoamuang 2006) and Apocyclops ramkhamhaengi from brackish water (Chullasorn et al. 2008). In comparison with other zoogeographical regions, the relatively low number of known and new taxa indicates the need for more intensive sampling in different regions and habitats in Thailand, including porous and fractured subterranean habitats, to improve our knowledge of copepod diversity in the Oriental region (Boxshall \& Defaye 2008) as well as of subterranean diversity on a global scale (Culver \& Sket 2000).

The diversity of aquatic subterranean fauna, either in karstic caves or gravel deposits in alluvium, has long been considered low compared to that in surface habitats. Sket (1999) gives explanations for the lack of diversity of habitats, including reduced ecotone between the surface and subsurface and restricted food resources. Because the dispersal of animals among caves is restricted, the species composition between caves can differ even if they are only a few kilometres apart. Limited possibilities of distribution result in a high degree of endemism (Gibert \& Deharveng 2002). Such distribution models contribute to the knowledge of groundwater diversity at a regional rather than at a local scale (Culver \& Sket 2000).

Without doubt, Copepoda is one of the most successful groups of invertebrates in subterranenan aquatic habitats. From more than 2800 known taxa in freshwater habitats world-wide (Boxshall \& Defaye 2008), there are about 1000 taxa recorded from subterranean habitats (Galassi 2001; Galassi et al. 2009), with the predominance of species of the orders Harpacticoida and Cyclopoida. Considering the cave environment, most freshwater cave-dwelling copepods are known from Europe, where they are present in saturated as well as in unsaturated zones of karstic aquifers. A bias in knowledge of the biodiversity of cave-dwelling copepods in Europe versus the rest of the world is an artefact due to the high number of researchers and taxonomists working predominantely in Europe. However, preliminary sampling campaigns in the last decade have revealed that a cave-dwelling copepod fauna is also present elsewhere (South America: Brancelj, pers. obs.; North America: Brancelj, pers. obs.; Pipan et al. 2006; Asia: Brancelj et al. 2010).

The first information on groundwater fauna from Thailand was the record of the stygobiotic (= obligate subterranean dweller) interstitial harpacticoid Elaphoidella margaritae Pesce \& Apostolov, 1985 collected from a well on Phuket Island (southern Thailand) along with the epigean Mesocyclops leuckarti (Claus, 1857) (Pesce \& Apostolov 1985), which probably refers to another species as revealed by Hołyńska et al. (2003) and Tran \& Hołynska (2015). Later, three widespread epigean cyclopoid species were recorded in subterranean environments: Tropocyclops prasinus (Fischer, 1860) in the Chiang Dao Cave (Deharveng \& Bedos 2000), and T. tenellus (G.O. Sars, 1909) and Microcyclops varicans (G.O. Sars, 1863) from a well in the northeast (Alekseev \& Sanoamuang 2006). In addition, a new genus and species of harpacticoid, Asiacaris dispar Cottarelli, Bruno \& Berera, 2010 and a new species, Kinnecaris iulianae Bruno \& Cottarelli, 2015, were recorded from the interstitial habitat of a sandy river bank on Pha-ngan Island (Cottarelli et al. 2010; Bruno \& Cottarelli 2015).

After 2007, intensive sampling of cave-dwelling copepods in northern Thailand resulted in the first discovery of a cave-dwelling stygobiotic harpacticoid, Elaphoidella namnaoensis Brancelj, Watiroyram \& Sanoamuang, 2010, followed by additional stygobiotic harpacticoids (three species) and cyclopoids (four species) (Watiroyram et al. 2012, 2015; Boonyanusith et al. 2013). 
In this paper, representatives of two new stygobiotic species of cyclopoids, collected in pools filled exclusively with dripping water from the ceiling of the caves, are described. Their original habitat is a thin layer of water, which fills small cracks and voids in shallow, superficial parts of karst, called the epikarst zone. It is the topmost part of an unsaturated karstic aquifer "in which climate, tree roots, and karst processes fracture and enlarge rock joints and cracks" (Bakalowicz 2005: 202-203). In that zone "rainfall infiltrates through the soil into the underlying bedrock, where it moves vertically through the pore spaces in the rock, displacing the air that occupied the pores" (White 2005: 293-300). Recently, several publications have demonstrated the importance of that zone in terms of the diversity of copepods living in caves (Brancelj 2002, 2006, 2009; Pipan \& Brancelj 2004; Brancelj et al. 2010).

\section{Material and methods}

Sampling was conducted in November 2009, at the end of Thailand's rainy season. Water dripping from the cave ceiling forms pools in the unsaturated zone during the rainy season. The pools were sampled from two caves, i.e., Chom Phon Cave and Khao Bin Cave located in Ratchaburi Province (central Thailand). Both caves are popular as tourist sites. For descriptions of the caves, see the 'Type locality' section.

In the Chom Phon Cave, samples were collected from plastic and aluminium buckets filled exclusively with percolating water. The water from the buckets was filtered by means of a special filtering bottle, fitted with a net of mesh size $60 \mu \mathrm{m}$ (Brancelj 2004). In the Khao Bin Cave, samples were collected from the pools on the floor of a gallery with a plankton-net with a $60 \mu \mathrm{m}$ mesh size. The pools were filled mainly by water seeping from the gallery's wall, and only occasionally by water dripping from the stalactites, but the water originated from the epikarst or the upper vadose zone.

A sample from each individual pool was stored in a plastic bottle immediately after sampling and fixed with formaldehyde to a final concentration of about $4 \%$. Specimens were sorted under a stereo microscope and stored in $70 \%$ alcohol. Before dissection, specimens were placed in a mixture of glycerol and $70 \%$ alcohol (ratio $\sim 1: 10 \mathrm{v} / \mathrm{v}$ ), which was replaced within one hour by pure glycerol. They were dissected at a magnification of 100× under an Olympus SZH 2 stereo microscope. All appendages and body ornamentation were examined under a compound microscope (Olympus BHS 40) at a magnification of $1000 \times$. All drawings, except for the female and male habitus, were made at the same magnification $(1000 \times)$, by means of a drawing tube. The final versions of the drawings were made in the CorelDRAW ${ }^{\circledR} 12$ graphic program. For permanent slides, all body parts were put in a drop of glycerol on a microscope slide, covered by a cover glass and sealed with nail polish.

The following institutional abbreviations are used throughout the text and figures:

KKU $=$ Science Museum of the Khon Kaen University (Khon Kaen, Thailand)

$\mathrm{NHM}=$ Natural History Museum (London, United Kingdom)

NIB = National Institute of Biology (Ljubljana, Slovenia)

The following descriptive abbreviations are used throughout the text and figures:

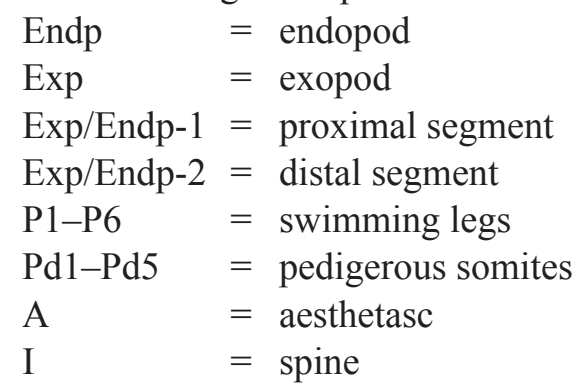

The nomenclature and descriptive terminology of body parts follow Huys \& Boxshall (1991). 


\title{
Results
}

Order Cyclopoida Burmeister, 1834

Family Cyclopidae Dana, 1846

Subfamily Cyclopinae Burmeister, 1834

\author{
Genus Siamcyclops gen. nov. \\ urn:1sid:zoobank.org:act:3D91D690-A08F-42F5-ADDE-C2BC2A39FE95
}

\section{Type species}

Siamcyclops cavernicolus gen. et sp. nov., by monotypy.

\section{Diagnosis}

Small Cyclopidae, with compact habitus and greatest width at posterior margin of cephalothorax. Antennule 11-segmented in female and 15-segmented in male. Genital double-somite wider than long, with obvious incision between anterior and posterior half of segment. Seminal receptacle small; anterior expansion slightly longer than posterior; anterior expansion wider than posterior one. Pd5 with lateral seta, vestige of baseoendopod of P5; two ventro-lateral setae on small knob. Anal operculum well developed; distal half of free margin serrated. Basis of antenna without seta representing Exp. Mandibular palp with three setae. Coxae of P1-P3 with seta on inner corner but absent on P4. P4 intercoxal sclerite with short obtuse prominence. P1-P4 with 2-segmented Exp and Endp, similar in length. Spine and setal formula on terminal segments of Exp P1-P4 as 3.3.3.2 and 5.5.5.5, respectively. Male genital somite swollen, globular in shape. Apical spine and inner subterminal seta on male P3 Endp modified.

\section{Etymology}

The genus is named after Siam, the ancient name for Thailand, prefixed to the existing generic name Cyclops.

\section{Remark}

Details on the justification for erecting the new genus are given in the section 'Differential diagnosis and remarks' for Siamcyclops cavernicolus gen. et sp. nov.

Siamcyclops cavernicolus gen. et sp. nov. urn:1sid:zoobank.org:act:33DF0C7F-AFB6-409A-A5B3-45ED0664B27C

Figs $1-5$

\section{Etymology}

The specific epithet cavernicolus meaning 'organism living in a cave', indicates its habitat. The epithet is a noun in the nominative singular masculine.

\section{Material examined}

\section{Holotype}

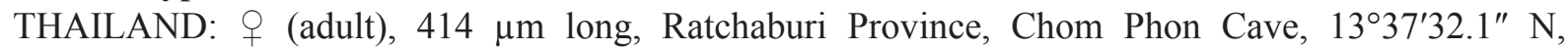
99 $35^{\prime} 14.2^{\prime \prime}$ E, 100 m a.s.l., filtering bottle, 21 Nov. 2009, C. Boonyanusith leg., completely dissected then mounted on a slide in glycerol and sealed with nail polish (NHM 2011.2080).

\section{Allotype}

THAILAND: $\widehat{\jmath}$ (adult), $394 \mu \mathrm{m}$ long, collected with the holotype, completely dissected, mounted on a slide in glycerol and sealed with nail polish (NHM 2011.2081). 


\section{Paratypes}

THAILAND: $2+q$ without egg sacs, 1 q with spermatophore, sampled with the holotype, whole specimens stored in 70\% alcohol (NHM 2011.2082-2084); 1 \% with spermatophore and egg sac, 1 + with spermatophore, 2 q 9 without egg sacs, sampled with the holotype, whole specimens stored in $70 \%$ alcohol (KKU-COP-2011-002); 2 +, 2 , 9 with egg sac, sampled with the holotype, whole specimens stored in $70 \%$ alcohol (NIB).

\section{Type locality}

The Chom Phon Cave is located in Chom Bung district, about $30 \mathrm{~km}$ west of the town of Ratchaburi. The cave is located in an isolated, small, limestone hill. It is a fossil cave, about $290 \mathrm{~m}$ long, with horizontal galleries only and the origin of the sampled water is exclusively drips of percolating water from the epikarst. The cave has two major openings. The first is an entrance located about $10 \mathrm{~m}$ above the valley floor at an elevation of $100 \mathrm{~m}$ a.s.1. The coordinates of the entrance are $13^{\circ} 37^{\prime} 32.1^{\prime \prime} \mathrm{N}, 99^{\circ} 35^{\prime} 14.2^{\prime \prime} \mathrm{E}$. Beyond the entrance is a long horizontal gallery at the same level as the valley floor and accessible without any special equipment except a lamp. The gallery is about $10 \mathrm{~m}$ wide and $8-10 \mathrm{~m}$ high and was formed by a subterranean river. The second opening, about $25 \mathrm{~m}$ in diameter, is located above the end-hall of the cave. There is a reclining Buddha statue and in a semi-illuminated place there are several plastic and aluminium buckets (= Buddha pots according to Brancelj et al. 2010) collecting dripping water from the cave walls and roots of trees for the whole year around. This is the type locality of Siamcyclops cavernicolus gen. et sp. nov. On the sampling date (21 Nov. 2009), no water was dripping from the cave walls or tree roots. The volume of water in the plastic buckets was about 51 and had a brown colour. The water temperature was $23.8^{\circ} \mathrm{C}, \mathrm{pH} 8.74$, and conductivity $435 \mu \mathrm{S} \mathrm{cm}^{-1}$. There was some guano and other organic debris in the buckets.

\section{Description}

\section{Female}

Body length, measured from tip of rostrum to posterior margin of caudal rami, 391-414 $\mu \mathrm{m}$ (mean: $404 \mu \mathrm{m} ; \mathrm{n}=10$ ); prosome/urosome ratio about 2.0 (Fig. 1A). Body dorsoventrally compressed. Preserved specimens transparent; naupliar eye not discernible; rostrum small, triangular. Cephalothorax anteriorly oval, as long as wide, with greatest width at posterior end of cephalosome; representing $41 \%$ of body length. Posterior margins of Pd1-Pd4 smooth. Integument smooth, not strongly chitinized, with no visible cuticular windows. Body width/length ratio 2.4. Genital double-somite well developed, about 1.4 times as wide as long, with pair of refractile, sclerotized, rounded, dorsolateral lobes (Fig. 1C); as long as following urosomites, including caudal rami; with well-discernible incision between anterior and posterior half of segment and tapering posteriorly (Fig. 1A-C). Copulatory pore small, oval, situated near middle of somite; copulatory duct short, narrow and well sclerotized. Seminal receptacle small, representing about $1 / 3$ of double-somite length, with anterior and posterior expansions; both expansions short but anterior one slightly longer, sclerotized and much wider compared to posterior one (Fig. 1B). Ovipores situated lateroposteriorly at about $1 / 2$ length of somite, covered with reduced P6 (Fig. 1D). Posterior margin of genital double-somite and two subsequent somites with hyaline fringes with irregular serration both ventrally and dorsally. Anal somite with well developed operculum, reaching $1 / 2$ length of caudal rami; distal half of free margin serrated; two large sensilla at base of operculum (Fig. 1C).

Caudal Rami (Fig. 1B-D). Slightly divergent; each about 1.5 times as long as wide. Anterolateral accessory seta (I) reduced. Anterolateral seta (II) bare, implanted at $2 / 3$ length of ramus; slightly shorter than ramus. Posterolateral seta (III) slim, about 1.2 times as long as ramus, implanted at $1 / 4$ of ramus length; insertion of seta ornamented with few spinules. Outer apical seta (IV) plumose; inner apical seta (V) longest; both setae bipinnatae, without fracture planes; inner one about twice as long as outer one and about 0.5 times as long as body. Apical accessory seta (VI) bare, spiniform, curved outward; about 
0.5 times as long as ramus. Dorsal seta (VII) bipinnate, inserted at distal inner corner of ramus, about twice as long as ramus.

ANTENNULE (Fig. 1E). 11-segmented, not reaching posterior margin of cephalothorax. Armature formula: 6.2.5.2.0+I.2.3.2+A.2.2+A.7+A. Fifth segment with short spine ventrally. Penultimate segment with aesthetasc near insertion of outer seta; aesthetasc as long as outer seta. Terminal segment with acrotheck subapically.

Antenna (Fig. 2A). 4-segmented; with coxobasis and 3-segmented Endp. Coxobasis with one smooth seta on distal inner corner; seta representing Exp absent. Endp-1 with longitudinal row of spinules along distal half of inner margin; with one smooth seta at $1 / 2$ length of margin. Endp-2 about 1.5 times as long as wide, with longitudinal row of minute spinules; along inner margin five smooth setae increasing in length (three laterally, one subapically, one apically). Endp-3 twice as long as wide, with longitudinal row of minute spinules; seven smooth setae apically (two of them robust and curved).

Mandible (Fig. 2B-C). With coxa and short basis partly fused with coxa. Gnathobase with strong chitinized teeth; ventralmost teeth very robust and slightly obtuse, with pinnate seta dorsally. Basis with one short and two long setae representing Exp and Endp, respectively; long setae about seven times as long as short seta.

MAXILLULE (Fig. 2D). With robust praecoxa and 2-segmented palp; proximal segment of palp coxobasis; distal one Endp. Arthrite of praecoxa with six strong spines laterally, five of them smooth; apically three claw-like spines decreasing in length and one weak seta. Coxobasis with three elements; one robust bipinnate seta accompanied by two weak smooth setae apically. Endp with two setae apically and one seta subapically. Exp represented by one seta.

Maxilla (Fig. 2E). 5-segmented. Endite of praecoxa prominent, with two plumose setae. Proximal endite of coxa with one plumose seta; distal endite elongate, with two bipinnate setae apically. Basis with clawlike basal endite, with row of spinules along concave margin; two setae at base of claw-like expansion; longest one as long as claw; other one shorter, 0.5 times as long as longer one. Endp 2-segmented; proximal segment with two robust setae; distal segment with one robust seta apically, as long as clawlike expansion on basis, accompanied by two slender, shorter setae.

MAXILLIPED (Fig. 2F). 4-segmented; syncoxa and basis with two pinnate setae each; basis with one row of spinules on distal outer margin; additional row of spinules laterally. Proximal segment of End with one strong seta. Distal segment armed with three setae, shortest one smooth.

P1-P4. With un-ornamented intercoxal sclerite, with deeply concave posterior margins; coxa rectangular; basis relatively triangular with slender outer seta; 2-segmented Exp and Endp (Fig. 3A-D). Coxa of P1$\mathrm{P} 3$ each armed with one plumose seta on inner distal corner. Exp-2 spine/seta formula: 3.3.3.2/5.5.5.5. Endp-2 spine/seta formula: 1.1.1.1/4.4.5.4. Complete armature of P1-P4 as follows (Roman numbers $=$ spines; Arabic numbers $=$ setae):

\begin{tabular}{|c|c|c|c|c|c|c|}
\hline \multirow[b]{2}{*}{ Swimming leg } & \multirow[b]{2}{*}{ Coxa } & \multirow[b]{2}{*}{ Basis } & \multicolumn{2}{|c|}{ Exopod } & \multicolumn{2}{|c|}{ Endopod } \\
\hline & & & 1 & 2 & 1 & 2 \\
\hline P1 & $0-1$ & $1-\mathrm{I}$ & $\mathrm{I}-0$ & II-I, 1-4 & $0-1$ & $1-\mathrm{I}-3$ \\
\hline P2 & $0-1$ & $1-0$ & $\mathrm{I}-0$ & II-I, 1-4 & $0-1$ & $1-\mathrm{I}, 1-2$ \\
\hline P3 & $0-1$ & $1-0$ & $\mathrm{I}-0$ & II-I, 1-4 & $0-1$ & $1-\mathrm{I}, 1-3$ \\
\hline P4 & $0-0$ & $1-0$ & $\mathrm{I}-0$ & $\mathrm{I}-\mathrm{I}, 1-4$ & $0-1$ & $1-\mathrm{I}, 1-2$ \\
\hline
\end{tabular}




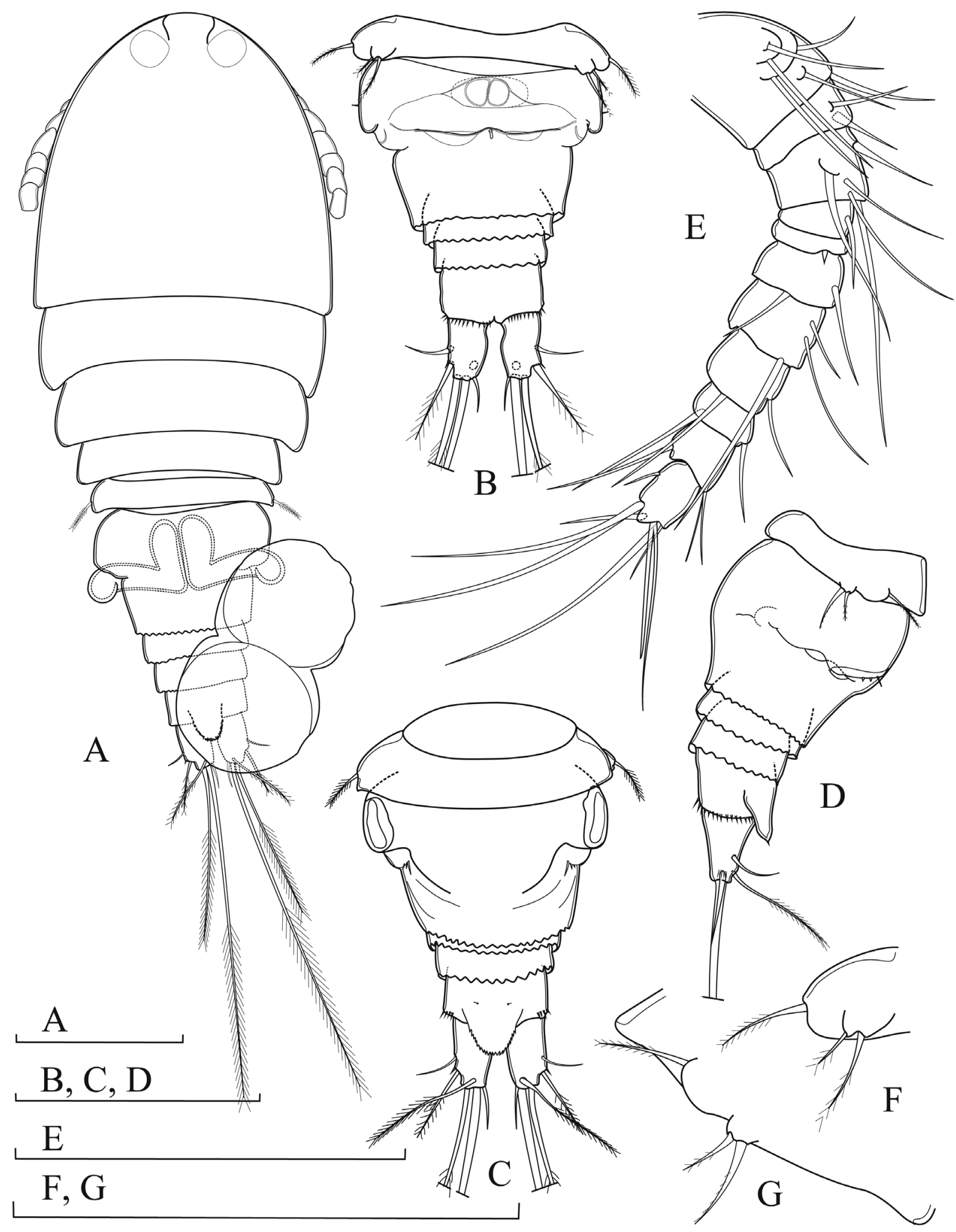

Fig. 1. Siamcyclops cavernicolus gen. et sp. nov., holotype, ${ }$. A. Habitus, with spermatophores and egg sac, dorsal view. B. Urosome, ventral view. C. Urosome, dorsal view. D. Urosome, lateral view. E. Antennule. F. P5, ventral view. G. P5, lateral view. Scale bars: $100 \mu \mathrm{m}$. 


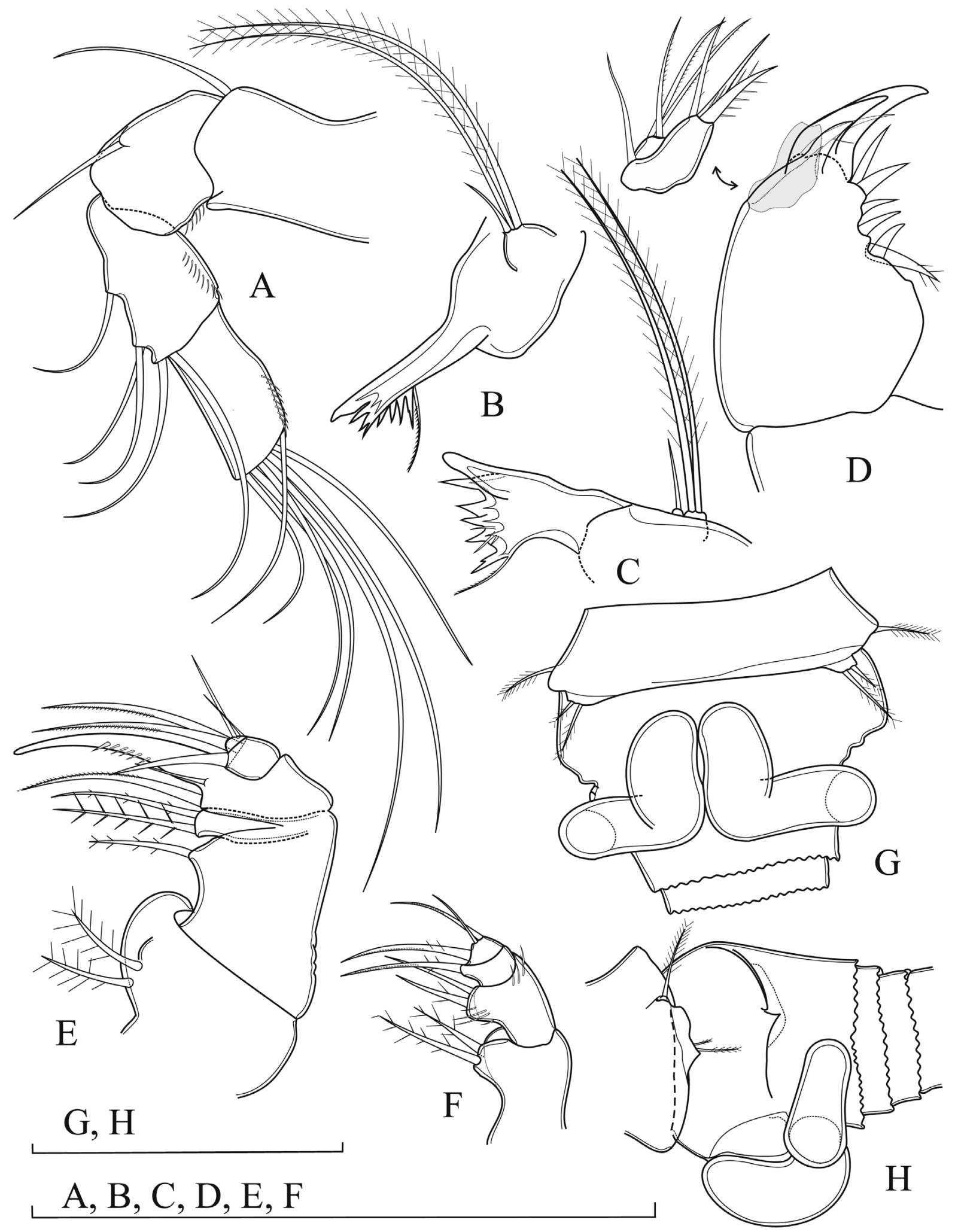

Fig. 2. Siamcyclops cavernicolus gen. et sp. nov., holotype, ․ A. Antenna. B-C. Mandible. D. Maxillule. E. Maxilla. F. Maxilliped. G. Genital double-somite with spermatophore, ventral view. H. Genital double-somite with spermatophore, lateral view. Scale bars: $100 \mu \mathrm{m}$. 
P1 (Fig. 3A). Exp-1 with one smooth, blunt, curved spine on outer corner. Exp-2 about twice as long as wide, apical setae as long as Exp-1 and -2 combined. Endp-1 shorter than wide, with sharply pointed extension on distal outer corner. Endp-2 1.3 times as long as wide, with one seta between 2 claw-like extensions on outer margin; very strong, blunt, hook-shaped spine apically.

P2 (Fig. 3B). Similar to P1, slightly less robust; apical spine on Endp-2 only slightly curved, as long as segment bearing it. Exp-2 1.5 times as long as wide.

P3 (Fig. 3C). Coxa, basis and Exp similar to those of P2. Endp-2 1.5 times as long as wide; terminal spine on Endp-2 straight, as long as segment bearing it.

P4 (Fig. 3D). Exp-2 twice as long as wide, with relatively weak pinnate spines on outer margin; apical setae longer than Exp-1 and 2 combined. Endp-1 large, 1.5 times as wide as long. Endp-2 1.3 times as long as wide, with short apical setae, only slightly longer than segment bearing them; apical spine short, about 0.5 times as long as segment bearing it.

P5 (Figs 1B-D, F-G, 2G-H). Reduced to 2 cuticular lobes, completely fused to Pd5, with three slender setae. Dorsal lobe broad, with one seta; ventral lobe small, with two unequal setae apically; longer seta about twice as long as shorter one.

P6 (Fig. 1D). Small, forming simple cuticular plate, inserted laterodorsally on genital double-somite, with two minute spines ventrally and one short seta dorsally.

SPERMATOphore (Fig. 2G-H). Paired; each forming 3-dimensional structure running in anterior-posterior direction ventrally, bending laterally at level of seminal receptacle and bending dorsally (as double flipped L); walls very thick.

EGG SAC (Fig. 1A). Extruded from gonopores laterodorsally, with two large eggs.

\section{Male}

Body length, measured from tip of rostrum to posterior margin of caudal rami, 381-402 $\mu \mathrm{m}$ (mean: $391 \mu \mathrm{m} ; \mathrm{n}=10$ ); prosome/urosome ratio about 2.0. Habitus (Fig. 4A) slightly smaller and more slender than in female. Naupliar eye not discernible; rostrum as in female. Cephalothorax and Pd 2-4 similar to those of female. Cephalothorax anteriorly oval, 1.1 times as long as wide, with greatest width at posterior end, representing $43 \%$ of body length. Posterior margins of Pd1-Pd4 smooth. Body length/width ratio about 2.3. Genital somite large, globular, about 0.9 times as long as rest of urosome, including caudal rami (Fig. 4A-D). Hyaline structures on dorsolateral part of genital somite well developed (Fig. 4A-D). Posterior border of genital somite with broad hyaline fringe with irregular serration dorsally. Subsequent three urosomites narrower than genital somite, with irregular serrated free hyaline fringes posteriorly. Anal somite and operculum as in female (Fig. 4A-D).

Caudal Rami (Fig. 4B-D). More slender than in female, about 1.6 times as long as wide. Anterolateral accessory seta (I) reduced. Anterolateral seta (II) bare, implanted at about $1 / 2$ length of ramus, slightly shorter than ramus. Posterolateral seta (III) bipinnate, about 1.2 times as long as ramus; insertion ornamented with few spinules. Outer apical seta (IV) plumose; without fracture plane. Inner apical seta (V) longest, plumose, about twice as long as seta IV and about 0.5 times as long as body length, without fracture plane. Apical accessory seta (VI) bare, spiniform, curved outward; about 0.5 times as long as ramus. Dorsal seta (VII) bipinnate, inserted at distal inner corner of ramus, about twice as long as ramus. 


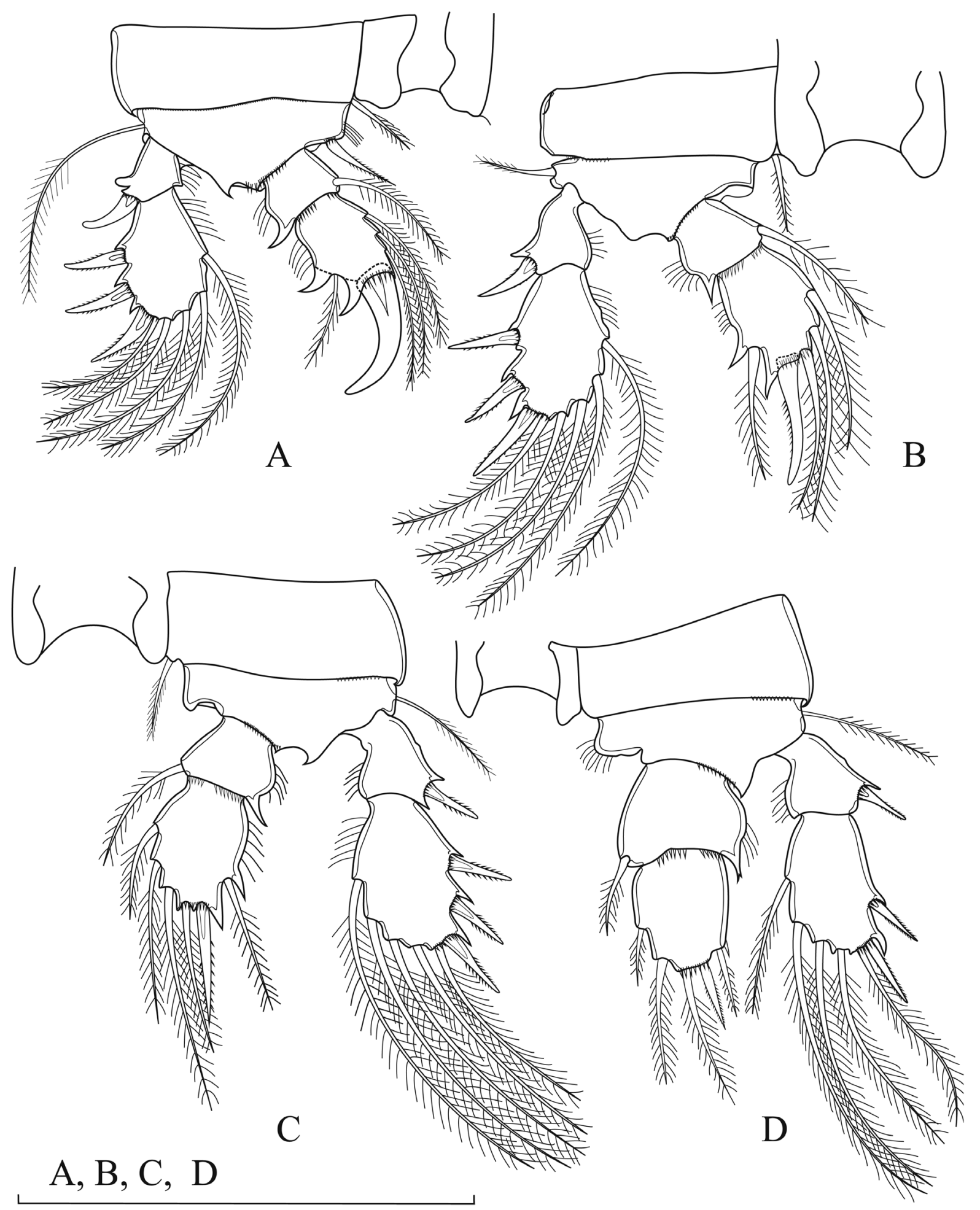

Fig. 3. Siamcyclops cavernicolus gen. et sp. nov., holotype, q. A. P1. B. P2. C. P3. D. P4. Scale bar: $100 \mu \mathrm{m}$. 


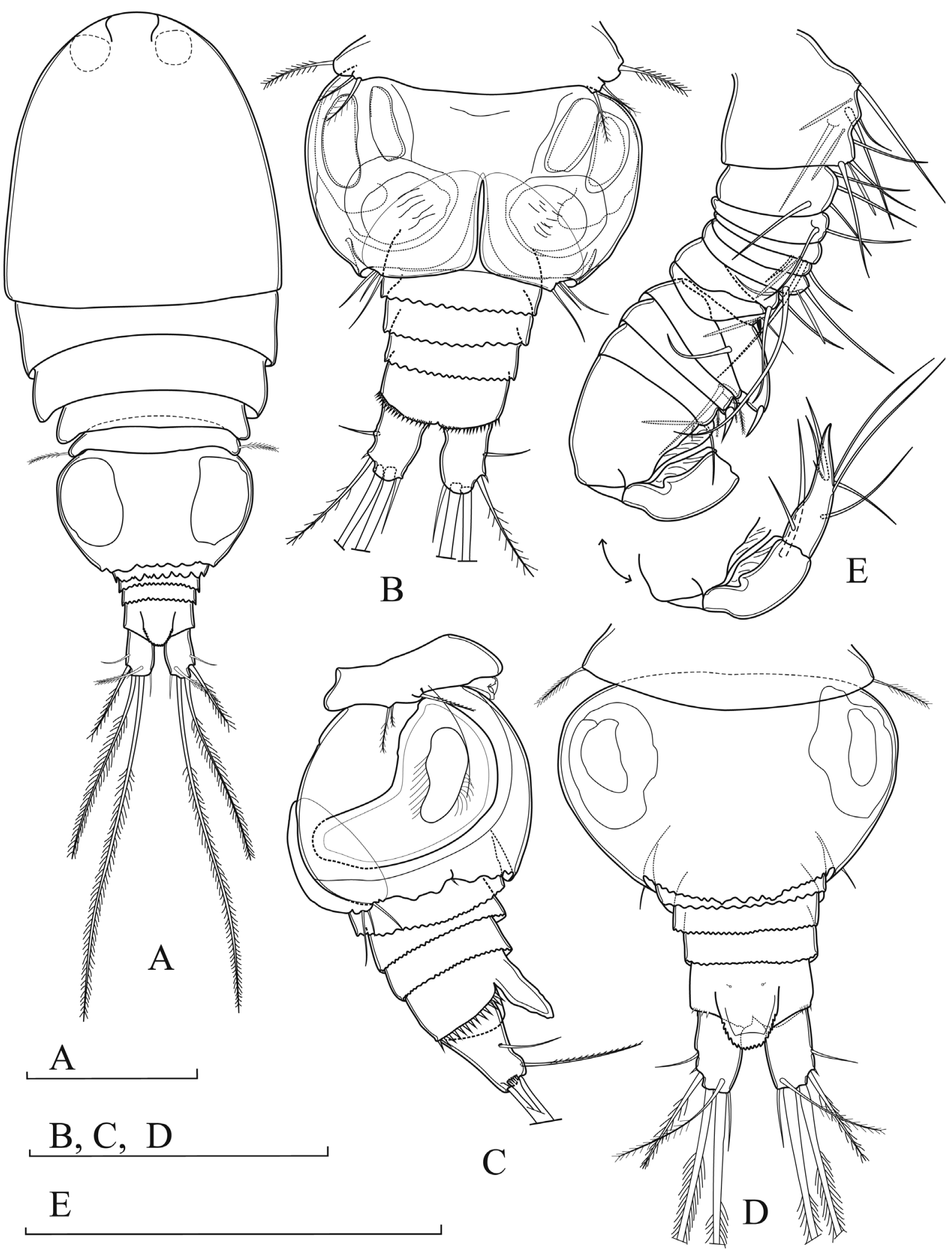

Fig. 4. Siamcyclops cavernicolus gen. et sp. nov., allotype, §. A. Habitus, dorsal view. B. Urosome, ventral view. C. Urosome, lateral view. D. Urosome, dorsal view. E. Antennule. Scale bars: $100 \mu \mathrm{m}$. 
AnTENNULE (Fig. 4E). 15-segmented, geniculate. Armature formula: 7+3A.4.2.2+A.1.2+A.3.1+A+I.2.2 $.2 .2+$ A.1.1.7+A. Terminal segment with acrotheck; short spine on eighth segment. Seta on ninth and eleventh segments robust, spiniform; seta on tenth, eleventh and twelfth segments very short, bipinnate.

Antenna, mouthparts, P1, P2 AND P5. As in female.

P3 (Fig. 5A). Exp as in female. Endp-2 with apical spine modified as spoon-like element; bent inward and ornamented with minute transverse denticles along distal $1 / 3$ of margin; tip of spine bent. Inner subterminal seta modified as claw-like spine, bare and bent toward apical spoon-like spine. Sub-terminal seta on outer margin very short.

P4 (Fig. 5B). Exp and Endp similar to those of female; Endp with relatively longer setae and spines compared to female.

P6 (Fig. 4B-C). Positioned ventrally; modified to large cuticular plate with three setae; middle one shortest; ventral one longest.

\section{Variability}

No significant variability was observed in females except minor variation in size, shape and number of spinules on some segments or somites. Variability not observed in males.

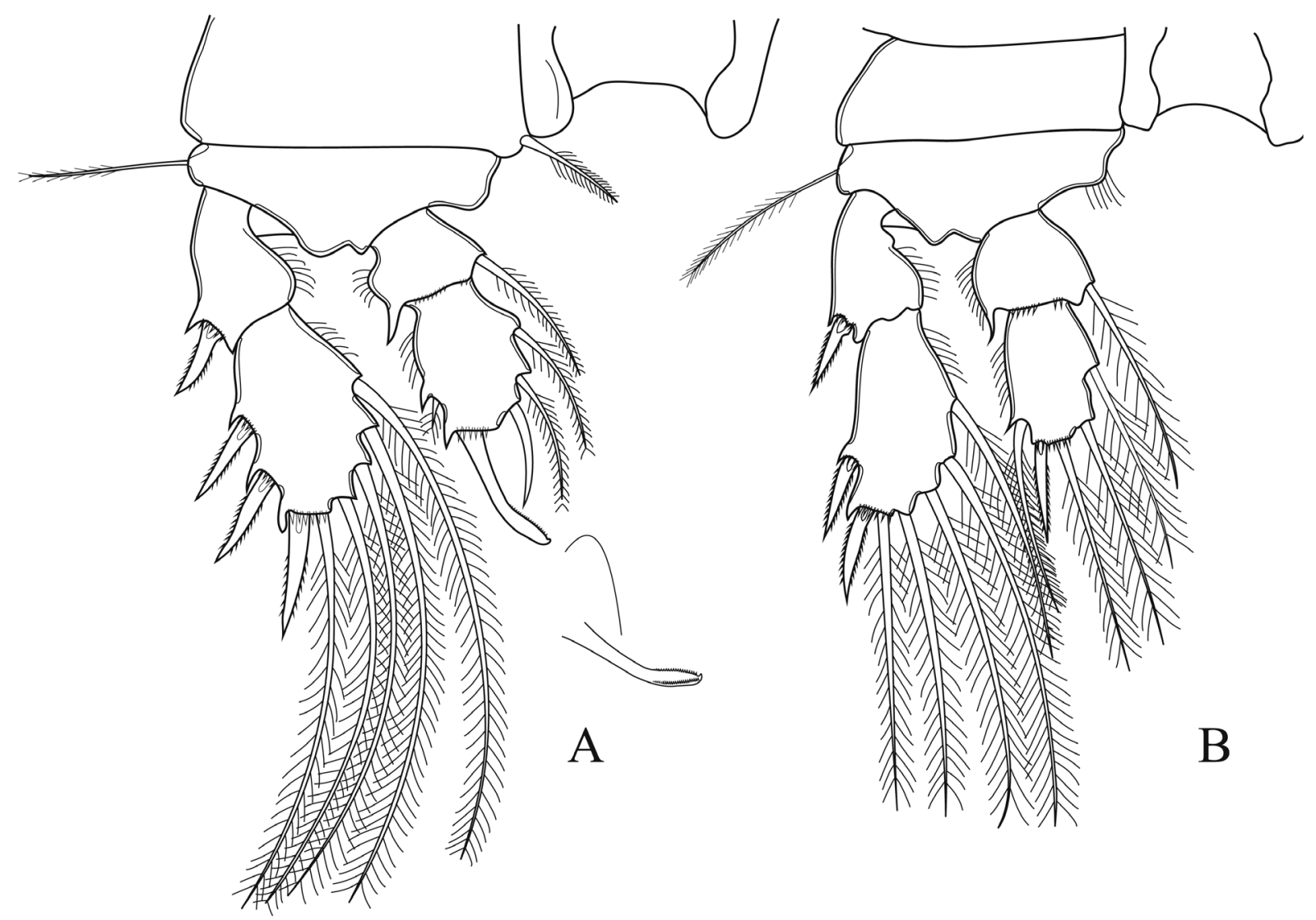

A, B

Fig. 5. Siamcyclops cavernicolus gen. et sp. nov., allotype, §. A. P3. B. P4. Scale bar: $100 \mu \mathrm{m}$. 


\section{Differential diagnosis and remarks}

Based on the number of segments of the antennules, the progressive oligomerization of P1-P4, and the shape and armature of P5, Pesce (1996) classified 33 genera in the subfamily Cyclopinae into 6 groups, including the Bryocyclops and Microcyclops groups, both presented in this paper. Most of the 33 classified genera also include stygobiotic members. Their morphological adaptations for life in subterranean habitats are related to specific environmental characteristics (i.e., lack of light and food scarcity) and include a reduction of body size, 10- or 11-segmented antennules, P1-P4 with three or two segmented Exp, two or one segmented Endp rami, and partly or completely fused P5 to Pd5. The level of reductions express a grade of a transformation of appendages from a plesiomorphic state (P1-P4 with three segmented Exp/Endp and P5 clearly separated from Pd5) to an apomorphic one (P1-P4 with reduced number of segments in Exp/Endp and P5 fused with Pd5) (Pesce 1996).

In stygobiotic Cyclopinae, intensive reductions of P5 have a strong effect on establishing a genus level (Reid \& Ishida 2000). For that reason, some other morphological characters should also be included to support the erection of a new genus as well as its position within six groups in the subfamily Cyclopinae. Examples of the effect of inclusion of other morphological characters in erecting a new genus and its positioning within six gropus of Cyclopinae include the morphologicaly similar genera Speocyclops Kiefer, 1937 (a member of Microcyclops group) and Bryocyclops Kiefer, 1927 (a member of Bryocyclops group). They are similar in body shape and both have very reduced P5 or even have it fused to Pd5 (Pandourski 1992; Dussart \& Defaye 2001; Galassi \& De Laurentiis 2004). The main discrimination character between both genera/groups is the presence/absence of a seta on the inner corner of the coxa in P4. In the genus Bryocyclops it is absent, while in the genus Speocyclops it is present.

There are some similar morphological details between the Microcyclops and Bryocyclops groups, also. An example is the modification of the P3 Endp-2 spine in the males observed in representatives of Bryocyclops and the Alaskan population of Itocyclops yezoensis (Itô, 1953) (member of the Microcyclops group). However, according to Reid \& Ishida (2000), there are no phylogenetic relationships between the genera Bryocyclops and Itocyclops Reid \& Ishida, 2000, and the modification of P3 might be a result of random mutation within the Alaskan population.

Absence of a seta on the inner corner of the coxa in P4 in the male and female as well as the modification of the P3 Endp-2 spine in the male place Siamcyclops gen. nov. in the Bryocyclops group. So far, representatives of genera Bryocyclops and Siamcyclops gen. nov. only differ from other genera within the Bryocyclops group by morphological modifications in armature elements on the male P3 Endp-2. The lack of a seta on the inner corner of the coxa of $\mathrm{P} 4$ in the male and female, combined with modifications of elements of the P3 Endp-2 in the male, indicate a close relationship between $S$. cavernicolus gen. et sp. nov. and the representatives of Bryocyclops groups I, II, V and VII (in group VII it is not modification but a difference in the size of the spine between the male and female) (Lindberg 1956; Reid 1999; Fiers 2002; Watiroyram et al. 2015).

A similarity in the shape of the P4 Endp-2 and the presence of six armature elements there (five in other Bryocyclops species) indicate that the new taxon most resembles B. jankowskajae Monchenko, 1972, known from the Kyzylkum Desert in Uzbekistan (formerly part of the USSR). The species was recently moved from the subgenus Palaeocyclops Monchenko, 1972 into Bryocyclops s. str. (Walter 2015). For that reason, we suggest the establishment of a new group, i.e., group VIII, to accommodate it within the genus Bryocyclops.

All representatives of the genus Bryocyclops (except B. bogoriensis (Menzel, 1926)) and the former member of the subgenus Palaeocyclops have a pointed prominence on the intercoxal sclerite of $\mathrm{P} 4$, while in $S$. cavernicolus gen. et sp. nov. it is obtuse. However, the armament on the mandibular palp and distal 
segment of P4 Exp found in representatives of the genus Bryocyclops, including a former member of the subgenus Palaeocylops, show a pattern of reduction of armature elements. The presence of only one or no seta can be observed in several species within the genus Bryocyclops where the mandibular palp was described or illustrated, as in B. saqotraensis Mirabdullayev, Van Damme \& Dumont, 2002, B. muscicola (Menzel, 1926), B. maewaensis Watiroyram, Brancelj \& Sanoamuang, 2012 and B. jankowskajae. The presence of 3 setae on the mandibular palp in S.cavernicoulus gen. et sp. nov. shows a plesiomorphic state of the character, which clearly differentiates it from members of the genus Bryocyclops.

Furthermore, the spine/seta formula 3.3.3.2/5.5.5.5 found in the new taxon differs clearly from the formulae of the species within the genus Bryocyclops, where the spine/seta formula varied from 2.2.2.2/5.4.4.3 (group V) to 2.3.3.3/ 5(4).4.4.3 (group VI), 3.3.3.2/ 5.4.4.4 (group III), 3.3.3.3 / 5.5.5.4 (groups I and VII), 3.3.3.3(4)/5(4).5.5.4 (group II), and 3.3.3.4/5.4.4.4 (group IV) (Lindberg 1947; Watiroyram et al. 2015). It also differs considerably from $B$. jankowskajae whose spine/setae formula is 2.3.3.3/5.5.5.4.

Normally, the spermatophores within the subfamily Cyclopinae are bean- or kidney-shaped. They have also been illustrated in some species of Bryocyclops such as B. caroli Bjornberg, 1985 and B. absalomi Por, 1981. The unique, three dimensional L-flip feature of the spermatophore observed in S.cavernicolus gen. et sp. nov. differs from those of other members of the genus Bryocyclops as well as from other members of the subfamily Cyclopinae.

For the reasons listed above, we propose the establishment of the new genus Siamcyclops gen. nov. to accommodate the new stygobiotic species from Thailand. The main differences between the three related taxa, Bryocyclops spp., Bryocyclops jankowskajae and Siamcylops gen. nov., are listed in Table 1.

\section{Key to genera and subgenera of the Bryocyclops group}

Common characteristics of the group are the following: a) 10- or 11-segmented antennules; b) rami of swimming legs 2-segmented but with additional oligomerization in some species; c) P5 completely fused with Pd5, with baseoendopodal seta laterally (a remnant of the proximal segment of P5 - coxa, basis and Endp), with 2 setae/spines sub-ventrally (a remnant of the Exp P5).

1. Position of P6 vestiges on the posterior half of genital double-somite

Haplocyclops Kiefer, 1952 (2)

- Position of P6 vestiges on the anterior half of genital double-somite

2. P1-P4 Exp-2 spine formula 2.3.3.2 ..................Haplocyclops (Haplocyclops) Kiefer, 1952

- P1-P4 Exp-2 spine formula 2.2.2.2

Haplocyclops (Kierfercyclops) Karanovic \& Ranga Reddy, 2005

3. P5 reduced to one stout spine on Exp lobe; coxa of P4 with one strong, spiniform seta Bacillocyclops Lindberg, 1956

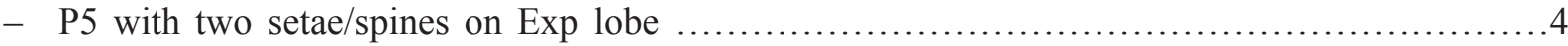

4. P5 remnant of Exp lobe with one spine and one seta; genital double-somite longer than wide; distal segment of P4 Endp with six elements; one spine and one seta apically ...Yansacyclops Reid, 1988

- P5 remnant of Exp lobe with two setae; genital double-somite as long as wide or wider than long ...5

5. P1 without median seta/spine on both coxa and basis; anterolateral seta (II) on caudal ramus positioned dorsally; P1-P4 Endp-2 spine formula 2.2.2.2 ....

Rybocyclops Dussart, 1982

- P1 with one seta/spine on coxa, basis with or without inner seta; anterolateral seta (II) on caudal ramus positioned dorsally or laterally; P1-P4 Endp-2 spine formula not 2.2.2.2 ...........6

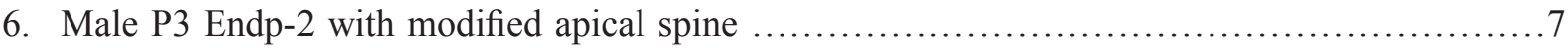

- Male P3 Endp-2 without modified apical spine ......................Allocyclops Kiefer, 1932 (8) 
Table 1. Differential diagnosis between the genus Bryocyclops ${ }^{*}$ Kiefer, 1927, Bryocyclops jankowskajae Monchenko, 1972 and Siamcyclops gen. nov. (Roman numbers = spine; Arabic numbers = seta).

* only members of groups I and II (according to Lindberg 1947) are included; details on other groups of spine/seta formulae are in the text

$\dagger$ in B. fidjiensis Lindberg, 1954

$\dagger \dagger$ in B. campaneri Rocha \& Carvalho Bjornberg, 1987

†† in B. bogoriensis (Menzel, 1926)

\begin{tabular}{|c|c|c|c|c|}
\hline & Character & Bryocyclops spp. & $\begin{array}{c}\text { Bryocyclops } \\
\text { jankowskajae }\end{array}$ & $\begin{array}{l}\text { Siamcyclops } \\
\text { gen. nov. }\end{array}$ \\
\hline 1. & $\begin{array}{l}\text { Spine/ setal formula of } \\
\text { P4 Exp }\end{array}$ & $\begin{array}{c}\mathrm{I}-0 ; \mathrm{II}-\mathrm{I}+1-3 \text { or } \mathrm{III}- \\
\mathrm{I}+1-3^{\dagger}\end{array}$ & $\mathrm{I}-0 ; \mathrm{II}-\mathrm{I}+1-3$ & $\mathrm{I}-0 ; \mathrm{I}-\mathrm{I}+1-4$ \\
\hline 2. & $\begin{array}{l}\text { Spine/ setal formula of } \\
\text { P4 Endp }\end{array}$ & $\begin{array}{c}1-\mathrm{I}+1-2 \text { or } \\
0-1 ; 1-\mathrm{I}+1-1^{\dagger}\end{array}$ & $0-1 ; 1-\mathrm{I}+1-2$ & $0-1 ; 1-\mathrm{I}+1-2$ \\
\hline 3. & $\begin{array}{l}\text { Spine formula of P1-P4 } \\
\text { Exp-2 }\end{array}$ & 3.3 .3 .3 or $3.3 .3 .4^{\dagger}$ & 2.3.3.3 & 3.3 .3 .2 \\
\hline 4. & $\begin{array}{l}\text { Setal formula of P1-P4 } \\
\text { Exp-2 }\end{array}$ & $\begin{array}{l}\text { 5.5.5.4 or } \\
4.5 .5 .4^{\dagger \dagger}\end{array}$ & 5.5.5.4 & 5.5.5.5 \\
\hline 5. & $\begin{array}{l}\text { Size and length of P4 } \\
\text { Endp }\end{array}$ & $\begin{array}{l}\text { Smaller and shorter than } \\
\text { exopodite }\end{array}$ & $\begin{array}{l}\text { Subequal; as long as } \\
\text { exopodite }\end{array}$ & $\begin{array}{c}\text { Subequal; as long as } \\
\text { exopodite }\end{array}$ \\
\hline 6. & $\begin{array}{l}\text { Prominence of P4 } \\
\text { intercoxal sclerites }\end{array}$ & Pointed or rounded ${ }^{1 \dagger \dagger}$ & Pointed & Obtuse \\
\hline 7. & P6 armament & 3 setae & 2 setae & 3 setae \\
\hline 8. & $\begin{array}{l}\text { Armament on } \\
\text { mandibular palp }\end{array}$ & 1 seta & no seta & 3 setae \\
\hline 9. & Armament on coxa & $\begin{array}{l}\text { With inner seta on P1 only } \\
\text { or without inner seta on } \\
\text { coxa }^{\dagger}\end{array}$ & $\begin{array}{l}\text { With inner seta on } \\
\text { P1-P3 }\end{array}$ & $\begin{array}{l}\text { With inner seta on } \\
\text { P1-P3 }\end{array}$ \\
\hline 10. & Shape of spermatophore & Kidney/bean-shaped & $? ?$ & $\begin{array}{l}\text { Three dimensional } \\
\text { L-flip }\end{array}$ \\
\hline
\end{tabular}

7. Intercoxal sclerite of P4 with obtuse, slightly rounded prominence; P4 Exp-2 with five setae, P4 Endp distinctly 2-segmented; mandibular palp armed with three setae

Siamcyclops gen. nov.

- Intercoxal sclerite of P4 with pointed or rounded prominence; P4 Exp-2 with four (only in B. jankowskajae with five) setae, P4 Endp with variable segmentation: 1-segmented, indistinctly 2 -segmented or distinctly 2-segmented; mandibular palp armed with one seta or seta absent ........ Bryocyclops Kiefer, 1927

8. Coxa of P1-P4 with seta in inner distal corner .9

- Coxa of P2-P4 without seta in inner distal corner ...Allocyclops (Stolonicyclops) Reid \& Spooner, 1998 
9. Antenna with seta representing Exp; P4 Endp-2 with one apical spine and one outer seta Allocyclops (Psammocyclops) Kieffer, 1955

- Antenna without seta representing Exp; P4 Endp-2 with two apical spines

Allocyclops (Allocyclops) Kieffer, 1932

\author{
Genus Metacyclops Kiefer, 1927 \\ Metacyclops thailandicus sp. nov. \\ urn:1sid:zoobank.org:act:5AA8A750-7102-4258-9992-52DB66BDE4F0
}

Figs $6-8$

\title{
Etymology
}

The specific epithet is derived from the country (Thailand) where the species was collected. It is a noun in the nominative singular masculine.

\section{Type material}

\section{Holotype}

THAILAND: $+9,475 \mu \mathrm{m}$ long, Ratchaburi Province, Khao Bin Cave, 13³5'25.6" N 9940'13.1" E, $78 \mathrm{~m}$ a.s.l., filtering bottle, 21 Nov. 2009, C. Boonyanusith leg., completely dissected and mounted on a slide in glycerol and sealed with nail polish (NHM 2011.2085).

\section{Paratypes}

THAILAND: $2 q q$ without egg sacs, $1 q$ with egg sacs, sampled with the holotype, whole specimens stored in 70\% alcohol (NHM 2011.2086-2088); 2 우 without egg sacs, same data as holotype,whole specimens stored in 70\% alcohol (KKU-COP-2011-004); 2 우, 2 우 with egg sacs, same data as holotype, whole specimens stored in 70\% alcohol (NIB).

\section{Type locality}

The Khao Bin Cave is situated in the Muang District, about $20 \mathrm{~km}$ west of the town of Ratchaburi. The cave is in a small limestone valley located in a national forest reserve area. It is an about $300 \mathrm{~m}$ long fossil cave, with horizontal galleries only. The entrance is at an elevation of $78 \mathrm{~m}$ a.s.l. The coordinates of the entrance are $13^{\circ} 35^{\prime} 25.6^{\prime \prime} \mathrm{N}, 99^{\circ} 40^{\prime} 13.1^{\prime \prime} \mathrm{E}$. Beyond the entrance, which is at the level of the valley's floor, is a horizontal gallery, easily accessible. The gallery is about $10 \mathrm{~m}$ wide and $8-10 \mathrm{~m}$ high, well decorated with stalagmites and stalactites. Some temporary pools are present, filled by dripping water in the rainy season. In the innermost part, there is a permanent pool, with a diameter of about $1 \mathrm{~m}$ and a depth of about $50 \mathrm{~cm}$, filled mainly by seeping water and occasionally by dripping water. This is the type locality of Metacyclops thailandicus sp. nov. On 21 Nov. 2009, the water depth was $45 \mathrm{~cm}$; the water was transparent, with a temperature of $25.1^{\circ} \mathrm{C}, \mathrm{pH} 8.15$ and conductivity of $557 \mu \mathrm{S} \mathrm{cm}^{-1}$. There was a slight amount of fine organic debris in the pool.

\section{Description}

Female

Body length, measured from tip of rostrum to posterior margin of caudal rami, 443-486 $\mu \mathrm{m}$ (mean: $473 \mu \mathrm{m} ; \mathrm{n}=10$ ); prosome/urosome ratio about 2.2 (Fig. 6A). Body dorsoventrally depressed. Preserved specimens transparent; naupliar eye not discernible; rostrum small, triangular. Cephalothorax anteriorly oval, as long as wide, representing $40 \%$ of body length; length/width ratio about 1.1, with greatest width at posterior end. Posterior margins of Pd1-Pd4 smooth. Integument smooth, not strongly chitinized, no cuticular windows visible. Body length/width ratio about 2.5; cephalothorax about 1.8 times as wide as genital double-somite. Genital double-somite well developed, about 0.7 times as long as rest of urosome, including caudal rami; tapering posteriorly and slightly indented at level of seminal receptacle (Fig. 6B, 


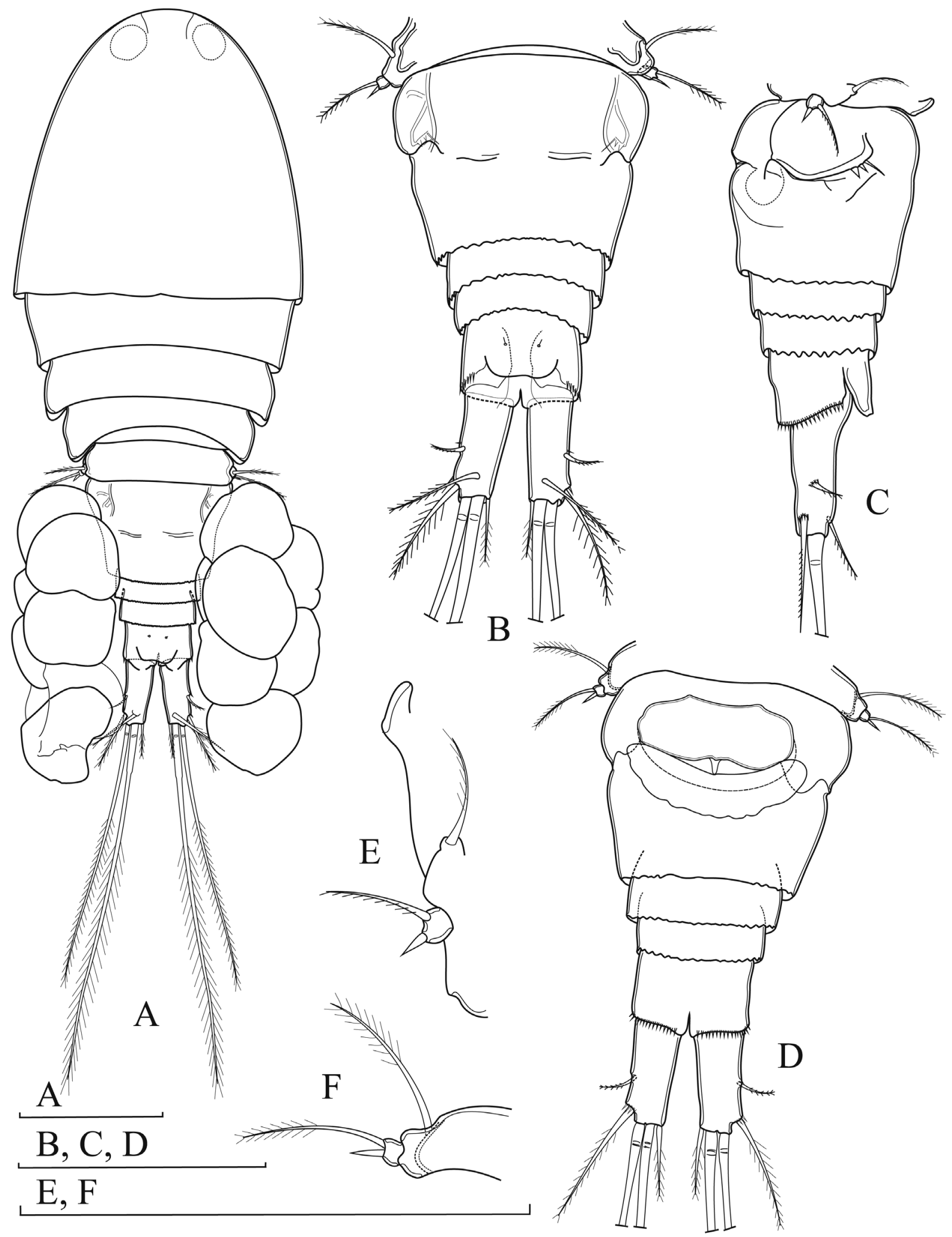

Fig. 6. Metacyclops thailandicus sp. nov., holotype,, . A. Habitus, with egg sac, dorsal view. B. Urosome, dorsal view. C. Urosome, lateral view. D. Urosome, ventral view. E. P5, lateral view. F. P5, ventral view. Scale bars: $100 \mu \mathrm{m}$. 
D). Genital double-somite about 1.25 times as wide as long (Fig. 6B, D). Copulatory pore small, ovoid, situated near $1 / 2$ length of double-somite; copulatory duct short, narrow and well sclerotized. Seminal receptacle with clear separation between anterior and posterior expansions; both expansions short; posterior more sclerotized and expanded laterally (Fig. 6D). Ovipores situated laterally, covered with reduced P6 (Fig. 6C). Posterior border of genital double-somite and two subsequent urosomites ornamented with hyaline fringes with irregular indentation dorsally and lateroventrally; slightly undulated ventrally. Anal somite with anal operculum reaching articulation of caudal rami; free margin smooth, slightly concave; two large sensilla at base of anal operculum (Fig. 6B).

CAudal RAmi (Fig. 6B-D). Slightly divergent; each ramus about 2.6 times as long as wide. Anterolateral accessory seta (I) reduced. Anterolateral seta (II) bipinnate, implanted at about $2 / 3$ length of ramus, shorter than ramus, near implantation of seta ornamented with few spinules. Posterolateral seta (III) slim, plumose, as long as ramus. Outer and inner apical setae (IV, V) plumose; with fracture planes; inner apical seta (V) 1.3 times as long as outer one (IV) and about 0.5 times as long as body length. Apical accessory seta (VI) straight, about 0.5 times as long as ramus. Dorsal seta (VII) plumose, inserted at about $3 / 4$ length of ramus; as long as ramus.

ANTENNULE (Fig. 7A). 11-segmented, not reaching posterior margin of cephalothorax. Armature formula: 7.2.5.2.2.2.3.2+A.2.2+A.7+A. First segment ornamented with transverse row of spinules on proximal anterior margin. Fifth segment with spiniform seta. Terminal segment with subapical acrotheck. Aesthetasc on eighth and tenth segments inserted near seta; aesthetasc on eighth segment shorter than seta, on tenth as long as seta.

AnTEnNa (Fig. 7B). 4-segmented; with coxobasis and 3-segmented Endp. Coxobasis with three setae; seta representing Exp not extending beyond Endp-2. Endp-1 with longitudinal row of spinules along distal half of inner (caudal) margin; with single smooth seta on outer margin. Endp-2 about 1.5 times as long as wide, with longitudinal row of minute spinules along inner margin and with five smooth setae along outer margin (three laterally, one subapically, one apically). Endp-3 segment twice as long as wide, with longitudinal row of minute spinules arranged in two rows, armed with seven smooth apical setae (two of them robust and curved).

MANDiBLE (Fig. 7C). With coxa and basis; gnathobase with strong chitinized teeth; ventralmost teeth robust and obtuse, dorsalmost sharp; pinnate seta dorsally. Mandibular palp 1-segmented, with one short and two very long setae. Two long setae about 8.0 times as long as short seta.

MAXILLULE (Fig. 7D). With robust praecoxa and 2-segmented palp; proximal segment of palp coxobasis; distal one Endp. Arthrite of praecoxa with six strong spines laterally; proximal one plumose, distal one smooth; apically with thee claw-like spines decreasing in length and one spiniform seta. Coxobasis with three elements; one robust bipinnate seta accompanied by two thin setae apically. Endp with two setae apically and one seta subapically. Exp represented by one seta.

MAXILLA (Fig. 7E). 5-segmented. Endite of praecoxa prominent, with two pinnate setae. Proximal endite of coxa with one pinnate seta; distal endite elongate, with two setae apically; longest one bipinnate, other one smooth; pinnate seta about 1.5 times as long as smooth one. Basis with claw-like basal endite, with a row of strong spinules along concave margin; distalmost the largest; two setae at base of claw; longest seta as long as claw; other seta 0.5 times as long as previous one. Endp 2-segmented; proximal segment with two robust setae, distal segment with one robust seta apically; as long as claw-like expansion on basis, accompanied by two slender, shorter setae. 


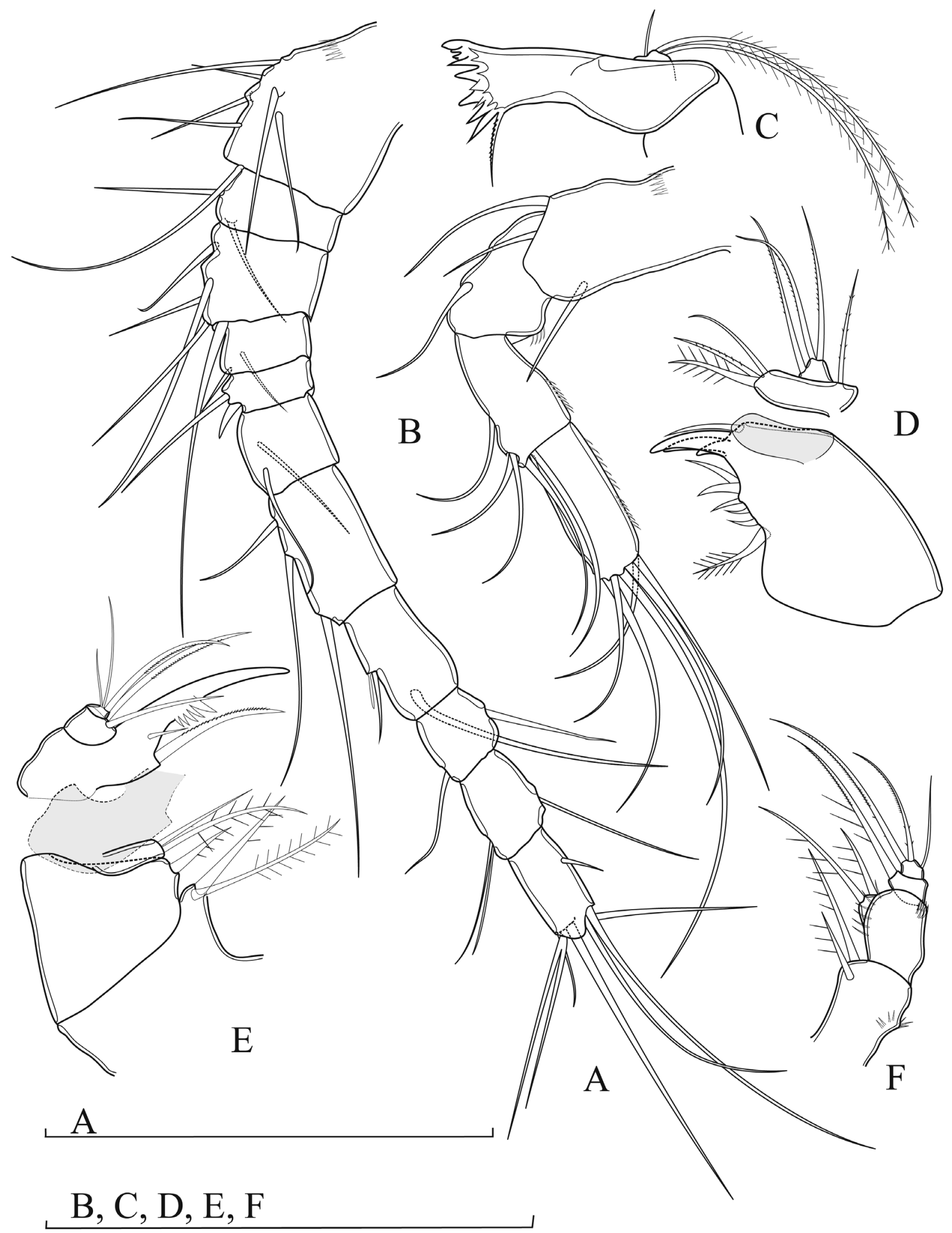

Fig. 7. Metacyclops thailandicus sp. nov., holotype, ․ A. Antennule. B. Antenna. C. Mandible. D. Maxillule. E. Maxilla. F. Maxilliped. Scale bars: $100 \mu \mathrm{m}$. 
MAXILLIPED (Fig. 7F). 4-segmented; syncoxa and basis with two unipinnate setae each; basis with a row of spinules on distal outer margin. Proximal segment of Endp with one robust, unipinnate seta; distal one armed with three setae; shortest seta smooth.

P1-P4. With unornamented intercoxal sclerite, with concave posterior margins; coxa rectangular with a row of spinules on distal outer corner, except P1; basis sub-triangular with slender outer seta with few spinules at implantation (Fig. 8A-D). Two-segmented Exp and Endp. Exp-2 spine/setal formula: 3.4.3.3/5.5.5.5. Endp-2 spine/setal formula: 1.1.1.1/5.6.6.4. Armature of P1-P4 as follows (Roman numbers $=$ spines; Arabic numbers $=$ setae):

\begin{tabular}{|c|c|c|c|c|c|c|}
\hline \multirow[b]{2}{*}{ Swimming leg } & \multirow[b]{2}{*}{ Coxa } & \multirow[b]{2}{*}{ Basis } & \multicolumn{2}{|c|}{ Exopod } & \multicolumn{2}{|c|}{ Endopod } \\
\hline & & & 1 & 2 & 1 & 2 \\
\hline $\mathrm{P} 1$ & $0-1$ & $1-\mathrm{I}$ & $\mathrm{I}-0$ & II-I, 1-4 & $0-1$ & $1-\mathrm{I}, 1-3$ \\
\hline $\mathrm{P} 2$ & $0-1$ & $1-0$ & $\mathrm{I}-1$ & III-I, 1-4 & $0-1$ & $1-\mathrm{I}, 1-4$ \\
\hline P3 & $0-1$ & $1-0$ & $\mathrm{I}-1$ & II-I, 1-4 & $0-1$ & $1-I, 1-4$ \\
\hline P4 & $0-1$ & $1-0$ & $\mathrm{I}-0$ & II-I, 1-4 & $0-1$ & $1-\mathrm{I}, 1-2$ \\
\hline
\end{tabular}

P1 (Fig. 8A). Exp-1 as long as wide; with short, blunt, curved spine on outer margin. Exp-2 as long as wide. Endp-1 0.7 times as long as wide. Endp-2 1.5 times as long as wide, with one outer seta between two claw-like cuticular extensions; strong, blunt, hook-shaped spine apically.

P2 (Fig. 8B). Exp-1 slightly longer than wide, with one curved smooth spine on outer corner. Exp-2 about 1.5 times as long as wide. Endp-1 as long as wide. Endp-2 about twice as long as wide; apical spine as long as segment bearing it.

P3 (Fig. 8C). Similar to P2 but Exp-2 with three spines along outer margin.

P4 (Fig. 8D). Exp-1 about 1.2 times as long as wide. Exp-2 about 2.2 times as long as wide; spines relatively slim and weak. Endp-1 as long as wide. Endp-2 slightly longer than wide; apical spine as long as segment bearing it.

P5 (Fig. 6E-F). With baseoendopod fused to Pd5, with one vestigial seta. Distal segment free, wider than long, with unipinnate apical outer seta and short inner spine. Apical seta about 4.0 times as long as inner spine.

P6 (Fig. 6C). Small, forming simple cuticular plate, inserted laterodorsally on genital double-somite, with three elements; dorsalmost short seta, other two very short, spiniform.

EGG SACS (Fig. 6A) Extruded from gonopores laterodorsally, with 5-8 eggs in each sac.

\section{Male}

Unknown.

\section{Differential diagnosis and remarks}

Metacyclops thailandicus sp. nov. differs clearly from the other members of the genus, including the most closely related M. cushae Reid, 1991. However, both species have some affinities to the genus Hesperocyclops Herbst, 1984, as well. The following are common characters shared among M. thailandicus sp. nov. from Thailand (South East Asia) and M. cushae from Louisiana (southern part of North America): a) antennules 11-segmented, b) spine formula of swimming legs P1-P4 3.4.3.3, c) P4 Endp-2 with one apical spine, d) intercoxal sclerite of swimming legs without ornamentation, e) apical accessory seta (VI) on caudal ramus shorter than posterolateral seta (III), f) antenna with 


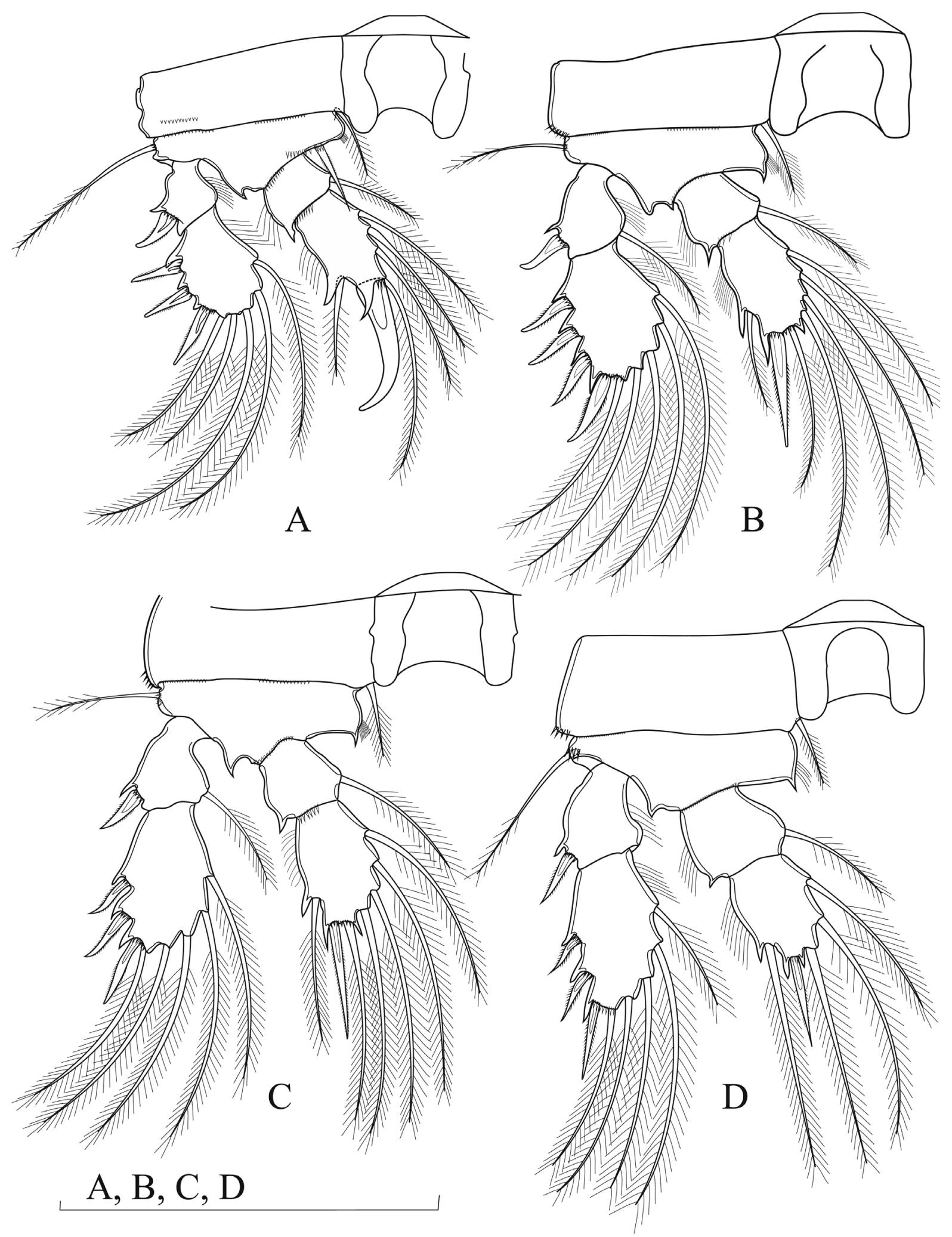

Fig. 8. Metacyclops thailandicus sp. nov., holotype, +. A. P1. B. P2. C. P3. D. P4. Scale bar: $100 \mu \mathrm{m}$. 
seta representing Exp not reaching tip of the Endp-2 segment, g) antenna Endp-2 with 5 setae. Three additional species similar to the new species, M. hannensis Defaye, 1992, M. ryukyuensis Ishida, 1995, and M. mortoni Pesce, De Laurentiis \& Humphreys, 1996, not included in the differential diagnosis of Reid (1991) between M. cushae and other representatives of the genus, also have one apical spine on P4 Endp-2, but M. hannensis and M. ryukyuensis have the spine the formula 3.4.4.3, while M. mortoni has 12-segmented antennules and spine formula 3.4.4.2.

Metacyclops thailandicus sp. nov. is distinct from M. cushae by the following characters: a) P1 Exp-1 without seta on its inner margin in M. thailandicus sp. nov., b) body without pitting ornamentation in M. thailandicus sp. nov., c) Endp-2 of antenna and the seventh segment of antennules are relatively longer in M. thailandicus sp. nov., d) caudal ramus length/width ratio in M. thailandicus sp. nov. is 2.6 compared to 3.0 in M. cushae, e) and maxilliped with surface ornamentation on syncoxa and basis in M. thailandicus sp. nov., which is absent in M. cushae.

The characteristic spine formula 3.4.3.3 and P4 Endp-2 with one element apically in $M$. thailandicus sp. nov. are the main differences between it and the rest of the members of the genus, where normally there are two spines apically. Four additional taxa, with one spine apically on P4 Endp-2, previously placed in the Metacyclops trispinosus group (Karanovic 2004) were recently placed in a new genus, Pescecyclops Karanovic, Eberhard \& Murdoch, 2011, which includes P. kimberleyi (Karanovic, 2004), P. laurentiisae (Karanovic, 2004), P. pilbaricus (Karanovic, 2004) and P. pilanus (Karanovic, 2004). They differ clearly from $M$. thailandicus sp. nov. and $M$. cushae by their spine formula, 3.3.3.3.

Considering the characters of the genus Hesperocyclops described by Herbst (1984) and emended by Galassi \& Pesce (1992), it is shown that the characters of M. thailandicus sp. nov. and M. cushae match well with it in: a) spine formula 3.4.3.3, b) apical accessory seta (VI) on caudal ramus shorter than posterolateral one (III), c) antenna with seta representing Exp, d) inner corner of basipodite of P1 with round prominence (well formed in M. cushae and less so in M. thailandicus sp. nov.), e) P5 Exp wider than long, two elements apically inserted far from each other. The significant difference between those two Metacyclops species and those of the genus Hesperocyclops is the modification of P4 Endp in females. In both Metacyclops species, P4 Endp of the female is not modified. The general modification of P4 Endp in Hesperocyclops is an expansion of the proximal segment. In some species, the proximal segment is completely fused with the distal one. On the other hand, normally 2-segmented P4 Endp was found in males of all representatives of the genus Hesperocyclops (Pesce 1985; Dussart \& Frutos 1986; Rocha \& Carvalho Bjornberg 1987; Galassi \& Pesce 1992).

Since the review of Cyclopinae two decades ago (Pesce 1996) and until now, 21 genera and subgenera have been added to the subfamily. So far, representatives of eight genera within the subfamily Cyclopinae have P5 with only one free segment (i.e., Exp), while the baseoendopod is completely fused with the Pd5. They have 2-segmented P1-P4 Exp/Endp and 10/11-segmented antennules. Of those eight genera, three (Meridiecyclops Fiers, 2001; Fierscyclops Karanovic, 2004; Pescecyclops Karanovic, Eberhard \& Murdoch, 2011) were established to accommodate some previous members of the genus Metacyclops Kiefer, 1927 (Fiers 2001; Karanovic 2004; Karanovic et al. 2011), while some others were synonymised, i.e., M. (Apocyclops) stocki Pesce, 1985 was recognised as a synonym of Hesperocyclops improvisus Herbst, 1984 (Galassi \& Pesce 1992). This indicates, probably, the polyphyletic nature of the genus Metacyclops and, thus, that a more detailed re-examination of both the P5 and many currently neglected (micro)characters, including sequence data, is urgently needed (Fiers 2001; Karanovic 2004). Many taxa from the Microcyclops group live in groundwater habitats (caves and interstitial water). Those habitats are characterised by specific ecological conditions, like scarcity of food, constant temperature, absence of light and, in interstitial waters, small spaces. In such habitats, convergent evolution can take 
place (i.e., through simplifications) (Sket 1985) and only analyses of gene sequences can resolve real relationships between taxa.

At present, representatives of 25 genera and subgenera of Cyclopinae can be included in the Microcyclops group. It is a morphologically very diverse group, occupying a wide array of habitats from epigean to subterranean. The species of the Microcyclops group are characterized by 10- or 11-segmented antennules, reduced P5, either as a separate segment or being more or less fused with the Pd5, usually as an elongated tubercle-like structure, and with P1-P4 2-segmented. However, there are exceptions: in the genus Hesperocyclops the female P4 Endp is 1-segmented, while in Itocyclops and Rheocyclops Reid \& Strayer, 1999 the female Exp is 3-segmented (Reid et al. 1999). The P5 Exp of the following genera has only one single seta: Cryptocyclops G.O. Sars, 1927; Neutrocyclops Kiefer, 1936; Idiocyclops Herbst, 1987. The genera with 2 setae/spines on the Exp are Anzcyclops Karanovic, Eberhard \& Murdoch, 2011; Apalachocyclops Fiers, 2011; Apocyclops Lindberg, 1942; Cochlacocyclops Kiefer, 1955; Dussartcyclops Karanovic, Eberhard \& Murdoch, 2011 (with subgenus Barrowcyclops Karanovic, Eberhard \& Murdoch, 2011); Fierscyclops Karanovic, 2004; Fimbricyclops Reid, 1993; Goniocyclops Kiefer, 1955; Graeteriella Brehm, 1926 (with subgenus Paragraeteriella Rylov, 1948); Hesperocyclops Herbst, 1984; Itocyclops Reid \& Ishida, 2000; Menzeliella Lindberg, 1954; Meridiecyclops Fiers, 2001; Metacyclops Kiefer, 1927; Microcyclops Claus, 1893 (inner spine strongly reduced and attached on inner edge or completely lost); Muscocyclops Kiefer, 1937; Pescecyclops Karanovic, Eberhard \& Murdoch, 2011; Pilbaracyclops Karanovic, Eberhard \& Murdoch, 2011; Psammophilocyclops Fryer, 1956; Rheocyclops Reid \& Strayer, 1999; Teratocyclops Pleşa, 1981 and Speocyclops Kiefer, 1937.

\section{Key to the genera and subgenera of the Microcyclops group}

Common characteristics of the group are the following: a) 10- or 11-segmented antennules, b) P1P4 with 2-segmented Exp and 1- or 2-segmented Endp (only exceptionally P3-P4 Exp 3-segmented), c) P5 with one free segment (i.e., Exp) or partly fused with the Pd5, with or without baseoendopodal seta.

1. P5 with one free distal segment or fused to Pd5; with one seta apically .......................2

- P5 with one free distal segment or fused to Pd5; with two setae/spines apically ..................6

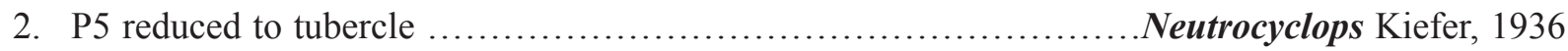

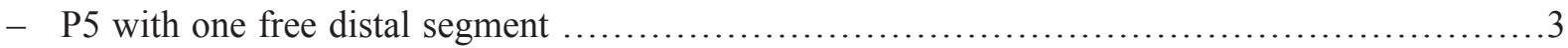

3. Caudal ramus with three terminal setae .............................Idiocyclops Herbst, 1987

- Caudal ramus with four terminal setae ...................................................

4. P4 Endp-2 with two apical spines, outer one much shorter and weaker than the other; coxal seta on P1-P4 thin and small; basis of P2-P4 with row of tiny spines on inner expansion ......

.Cryptocyclops G.O. Sars, 1927

- P4 Endp-2 with two well developed apical spines (exceptionally one spine); coxal seta on P1P4 clearly overreaching basis; basis of P2-P4 with fine hairs on inner expansion

Microcyclops Claus, 1893 (5)

5. P4 Endp-2 with two apical spines ......................Microcyclops (Microcyclops) Claus, 1893

- P4 Endp-2 with one apical spine ...............Microcyclops (Mediocyclops) Dussart \& Sarnita, 1986

6. Pd3-Pd5 with rows of long spinules laterally

Fimbricyclops Reid, 1993

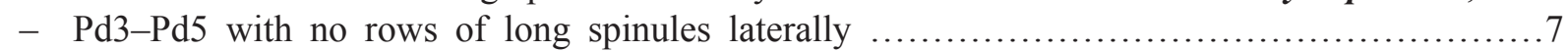

7. Pd5 without lateral seta (vestige of the basis of P5) ..................Graeteriella Brehm, 1926 (8)

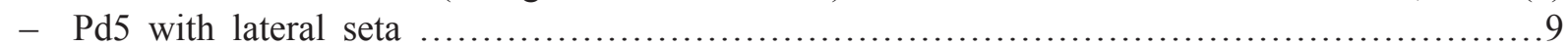


8. Caudal ramus with five setae; P4 Exp with 2-segmented ramus

Graeteriella (Graeteriella) Brehm, 1926

- Caudal ramus with six setae; P4 Exp with 3-segmented ramus

Graeteriella (Paragraeteriella) Rylov, 1948

9. Proximal half of genital double-somite with two sclerotized external parallel crests ventrally; inner margin of basis and P4 Endp-1 expanded

Meridiecyclops Fiers, 2001

- Genital double-somite without modified structures ventrally; inner margin of basis with or without expansion; P4 Endp-1 without expansion ................................................ 10

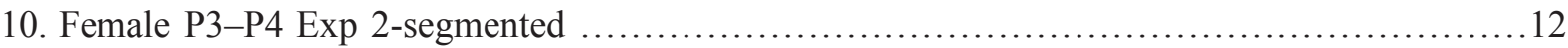

- Female P3-P4 Exp 3-segmented; if P4 Exp 2-segmented, anal operculum not extending beyond articulation of caudal ramus

11. Anal operculum well developed, irregularly triangular shaped; reaching beyond articulation of caudal ramus; A2 Endp-2 with eight setae

Itocyclops Reid \& Ishida, 2000

- Anal operculum short, not reaching beyond articulation of caudal ramus; A2 Endp-2 with six or seven setae

.Rheocyclops Reid \& Strayer, 1999

12. Male P3-P4 Exp 3-segmented; number of segments of P3-P4 Exp sexual dimorphic character Apalachocyclops Fiers, 2011

- Male P3-P4 Exp 2-segmented; number of segments of P4 Endp not sexual dimorphic character ...13

13. P5 with considerable distance between two elements apically 14

- P5 with spine and seta inserted close to each other; if P5 with considerable distance between two elements apically, female P4 Endp similar in shape to other swimming legs ..................... 15

14. Female P4 Endp 2-segmented; with one spine and one seta apically ......Apocyclops Lindberg, 1942

- Female P4 Endp 1- or 2-segmented, conspicuously modified, very different from that of male; with one spine apically

Hesperocyclops Herbst, 1984

15. P5 with free distinct segment; with one robust, blade-like spine and one seta; spine on distal segment of P5 as long as seta; anterior part of caudal ramus with a row of spinules dorsoventrally

Menzeliella Lindberg, 1954

- P5 with or without free distinct segment; apical elements on segment with two setae or one seta

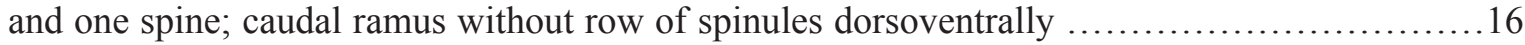

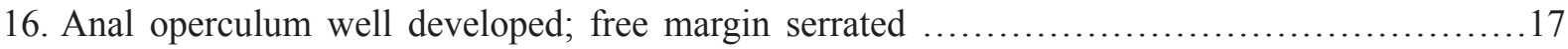

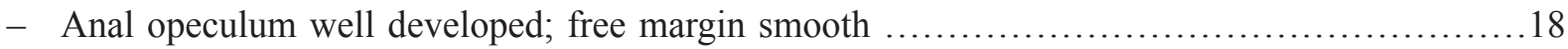

17. Spine formula 3.4.4.3

Speocyclops Kiefer, 1937

- Spine formula 2.3.3.2 Muscocyclops Kiefer, 1937

18. P2 Exp-2 with four spines; if three spines, P3 Exp-2 with three spines and P4 Endp-2 with two

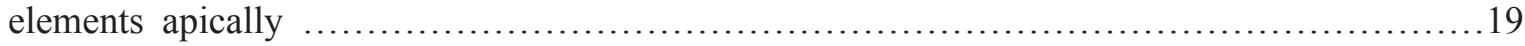

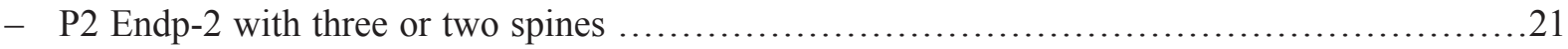

19. Genital double-somite barrel-shaped; P4 Endp-2 with one slender, setiform spine apically, twice as long as segment bearing it; outer apical seta (IV) on caudal ramus with geniculation (to prevent breaking)

Teratocyclops Pleşa, 1981

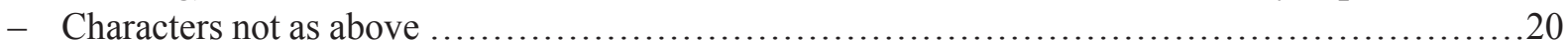

20. P5 with robust spine and short seta, spine about 0.5 times as long as seta; caudal ramus with large anterolateral accessory seta (I)

Fierscyclops Karanovic, 2004 
BOONYANUSITH C. et al., New stygobiotic cyclopoid genus from Thailand

- P5 with spine and long seta, spine less than 0.5 times as long as seta; caudal ramus without anterolateral accessory seta (I) ..................................Metacyclops Kiefer, 1927

21. Caudal ramus with large anterolateral accessory seta (I)

Pilbaracyclops Karanovic, Eberhard \& Murdoch, 2011

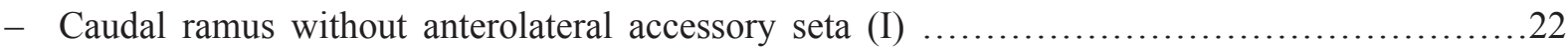

22. P1 Exp-2 with three spines; if two spines caudal ramus more than twice as long as wide ..........23

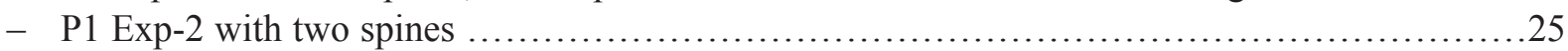

23. Caudal ramus more than three times as long as wide; if less, distal segment of P5 free; with one spine and one seta apically .................Pescecyclops Karanovic, Eberhard \& Murdoch, 2011

- Caudal ramus less than 2.6 times as long as wide; if more, distal segment of P5 fused to Pd5; with two setae apically

24. Seminal receptacle well developed, three foiled, posterior part circular; spine formula 3.3.3.2 ..... Cochlacocyclops Kiefer, 1955

- Seminal receptacle less developed posteriorly; spine formula 3.3.3.2, 3.3.3.3 or 2.2.2.2

Goniocyclops Kiefer, 1955

25. P2 Endp-2 with three spines

Anzcyclops Karanovic, Eberhard \& Murdoch, 2011

- P2 Endp-2 with two spines Dussartcyclops Karanovic, Eberhard \& Murdoch, 2011 (26)

26. P5 distal segment free ......Dussartcyclops (Dussartcyclops) Karanovic, Eberhard \& Murdoch, 2011

- P5 distal segment fused to Pd5

Dussartcyclops (Barrowcyclops) Karanovic, Eberhard \& Murdoch, 2011

\section{Discussion}

The list of subterranean Copepoda from alluvial and karstic aquifers in Southeast Asia (i.e., Cambodia, Indonesia, Laos, Malaysia, Myanmar, Philippines, Thailand and Vietnam), a total karstic surface area of $408000 \mathrm{~km}^{2}$, currently includes 31 species (Table 2). They were recorded in five countries: Indonesia (one cyclopid and one harpacticoid species), Malaysia (one harpacticoid species), Philippines (two cyclopoid and four harpacticoid species), Thailand (four cyclopoid and eleven harpacticoid species) and Vietnam (three calanoid, two cyclopoid and four harpacticoid species). The list includes three genera of Calanoida (Boholina Fosshagen \& Illife, 1989; Hadodiaptomus Brancelj, 2005; Nannodiaptomus Dang \& T.H. Ho, 2001), five genera of Cyclopoida (Bryocyclops Kiefer, 1927; Fierscyclops Karanovic, 2004; Graeteriella Brehm, 1926; Halicyclops Norman, 1903; Mesocyclops G.O. Sars, 1914) and nine genera of Harpacticoida (Asiacaris Cottarelli, Bruno \& Berera, 2010; Attheyella Brady, 1880; Elaphoidella Chappuis, 1928; Epactophanes Mrazek, 1893; Kinnecaris Jakobi, 1972; Microarthridion Lang, 1944; Nitocra Boeck, 1865; Parastenocaris Kessler, 1913; Phyllognathopus Mrazek, 1893).

This is a relatively low number of recorded species compared to Slovenia (Europe; area of $20000 \mathrm{~km}^{2}$ ) which is considered as a hot spot of groundwater fauna (Deharveng et al. 2009), where one calanoid species belongs to the genus Troglodiaptomus Petkovski, 1978; 18 cyclopoid species belong to the genera Acanthocyclops Kiefer, 1927, Diacyclops Kiefer, 1927, Graeteriella Brehm, 1926, Metacyclops Kiefer, 1927 and Speocyclops Kiefer, 1937; and 26 harpacticoid species belong to the genera Bryocamptus Chappuis, 1929, Ceuthonectes Chappuis, 1924, Elaphoidella Chappuis, 1928, Lessinocamptus Stoch, 1997, Moraria T. Scott \& A. Scott, 1893, Morariopsis Borutzky, 1931, Nitocra Boeck, 1865, Nitocrella Chappuis, 1923, Paramorariopsis Brancelj, 1992, Parastenocaris Kessler, 1913 and Pseudomoraria Brancelj, 1994 (Brancelj, unpubl. data). Without doubt, Southeast Asia has the potential for a high number of new subterranean Copopoda species, as evidenced by the recent results of research activities on cave-dwelling fauna in the karst areas of Thailand. 
Table 2. Stygobiotic Copepoda recorded in Southeast Asia $\left({ }^{\dagger}=\right.$ stygophile?; $\#=$ collected in anchialine cave).

\author{
Calanoida \\ "Boholina crassicephala Fosshagen, 1989; Philippines \\ \#Boholina purgata Fosshagen, 1989; Philippines \\ Hadodiaptomus dumonti Brancelj, 2005; Vietnam \\ Nannodiaptomus phongnhaensis Tran \& Brancelj, 2017; Vietnam \\ Nannodiaptomus haii Tran \& Brancelj, 2017; Vietnam
}

\title{
Cyclopoida
}

Bryocyclops maewaensis Watiroyram, Brancelj \& Sanoamuang, 2012; Thailand

Bryocyclops maholarnensis Watiroyram, Brancelj \& Sanoamuang, 2015; Thailand

Fierscyclops solaris Boonyanusith, Brancelj \& Sanoamuang, 2013; Thailand

Fierscyclops tanaosriensis Boonyanusith, Brancelj \& Sanoamuang, 2013; Thailand

Graeteriella longifurcata Tran \& Chang, 2013; Vietnam

"Halicyclops thermophilus Kiefer, 1929; Indonesia

Mesocyclops sondoongensis Tran \& Holynska, 2015; Vietnam

\section{Harpacticoida}

Asiacaris dispar Cottareli, Bruno \& Berera, 2010; Thailand Attheyella (Canthosella) vietnamica Borutzky, 1967; Thailand, Vietnam

'Elaphodella bidens decorata (Sars, 1904); Indonesia, Thailand

Elaphoidella jaesornensis Watiroyram, Brancelj \& Sanoamuang, 2013; Thailand

Elaphoidella ligorae Watiroyram, Sanoamuang \& Brancelj, 2017; Thailand

Elaphoidella margaritae Pesce \& Apostolov, 1985; Thailand

Elaphoidella namnaoensis Brancelj, Watiroyram \& Sanoamuang, 2010; Thailand

Elaphoidella paraffinis Watiroyram, Sanoamuang \& Brancelj, 2017; Thailand

Elaphoidella sanoanmuangae Watiroyram \& Brancelj, 2016; Thailand

Elaphoidella thailadensis Watiroyram, Brancelj \& Sanoamuang, 2013; Thailand

Elaphoidella vietnamica Borutzky 1967; Vietnam

Epactophanes philippinus Bruno \& Cottarelli, 1999; Philippines

Kinnecaris iulianae Bruno \& Cotarelli, 2015; Thailand

"Microarthridion thanhi Tran \& Chang, 2012; Vietnam

"Nitocra vietnamensis Tran \& Chang, 2012; Vietnam

Parastenocaris arganoi Cotarelli \& Mura, 1982; Malaysia

Parastenocaris mangyans Bruno \& Cottarelli, 1999; Philippines

Parastenocaris distincta Cottarelli, Bruno \& Berera, 2006; Philippines

Phyllognathopus bassoti Rouch, 1972; Philippines

Intensive sampling in caves in Thailand over the last ten years, particularly in the upper part of the vadose zone called the epikarst, has provided more than 10 new species of copepods (Table 2). They belong to two orders: Cyclopoida and Harpacticoida. So far, most of the new species belong to already known genera, with Bryocyclops and Fierscyclops (Cyclopoida) and Elaphoidella (Harpacticotida) being the most common.

Siamcyclops gen. nov. is the first representative of a new genus from the epikarst in Thailand and in Southeast Asia as a whole. At the same time it is the sixth groundwater dwelling genus of Cyclopoida recorded in Southeast Asia. With more intensive research of subterranean habitats, new species and new genera are expected, as well as better insights into their geographical distribution. Due to the fragmented nature of karstic areas in Southeast Asia, further endemic species and genera will undoubtedly be discovered. 


\section{Acknowledgements}

This work was supported by the Commission on Higher Education, Thailand, under the program Strategic Scholarships for Frontier Research Network, and by Programme P1-0255 supported by the Slovenian Research Agency. Stephanie Sullivan is thanked for her help with the English corrections and two anonymous reviewers for their useful comments on an earlier version of the paper.

\section{References}

Alekseev V.A. \& Sanoamuang L. 2006. Biodiversity of cyclopoid copepods in Thailand - with a description of Afrocyclops henrii sp. n. Arthropoda Selecta 15: 277-290.

Bakalowicz M. 2005. Epikarst. In: Culver D.C. \& White W.B. (eds) Encyclopedia of Caves: 220-223. Elsevier Academic Press, Amsterdam.

Boonyanusith C., Brancelj A. \& Sanoamuang L. 2013. First representatives of the genus Fierscyclops Karanovic, 2004 (Copepoda, Cyclopidae) from South East Asia. Journal of Limnology 72: 275-289. https://doi.org/10.4081/jlimnol.2013.s2.e13

Boonsom J. 1984. The freshwater zooplankton of Thailand (Rotifera and Crustacea). Hydrobiologia 113: 223-229. https://doi.org/10.1007/BF00026610

Boxshall G.A. \& Defaye D. 2008. Global diversity of copepods (Crustacea: Copepoda) in freshwater. Hydrobiologia 595: 195-207. https://doi.org/10.1007/s10750-007-9014-4

Brancelj A. 2002. Microdistribution and high diversity of Copepoda (Crustacea) in a small cave in central Slovenia. Hydrobiologia 477: 59-72. https://doi.org/10.1023/A:1021043014879

Brancelj A. 2004. Biological sampling methods for epikarst water. In: Jones W.K., Culver D.C. \& Hernan J.S. (eds) Epikarst: Proceedings of the Symposium held October 1 through 4, 2003, Shepherdstown, West Virginia, USA, (Special Publication, 9). Charles Town (West Virginia): 99-103. Karst Waters Institute, Charles Town.

Brancelj A. 2006. The epikarst habitat in Slovenia and the description of a new species. Journal of Natural History 40: 403-413. https://doi.org/10.1080/00222930600646608

Brancelj A. 2009. Fauna of an unsaturated karstic zone in central Slovenia: two new species of Harpacticoida (Crustacea: Copepoda), Elaphoidella millennii n. sp. and E. tarmani n. sp., their ecology and morphological adaptations. Hydrobiologia 621: 85-104.

https://doi.org/10.1007/s10750-008-9634-3

Brancelj A., Watiroyram S. \& Sanoamuang L. 2010. The first record of cave-dwelling Copepoda from Thailand and description of a new species: Elaphoidella namnaoensis n. sp. (Copepoda, Harpacticoida). Crustaceana 83: 779-793. https://doi.org/10.1163/001121610X502894

Bricker K.S., Wongrat L. \& Gannon J.E. 1978. Composition and distribution of crustacean plankton in 12 inland water bodies of Thailand. Kasetsart University Fisheries Research Bulletin 10: 1-14.

Bruno M.C. \& Cottarelli V.2015. Firstrecord of Kinnecaris (Copepoda:Harpacticoida:Parastenocarididae) from Turkey and Thailand; description of three new species and emended definition of the genus. Italian Journal of Zoology 25: 1-26.

Chaicharoen R., Sanoamuang L. \& Hołyńska M. 2011. A review of the genus Thermocyclops (Crustacea: Copepoda: Cyclopoida) in Cambodia. Zoological Studies 50: 780-803.

Chullasorn S., Kangtia P., Pinkaew K. \& Ferrari F.D. 2008. Apocyclops ramkhamhaengi sp. nov. (Copepoda: Cyclopoida) in a culture originating from brackish waters of Chang Island, Trat Province, Thailand. Zoological Studies 47: 326-337. 
Cottarelli V., Bruno M.C. \& Berera R. 2010. First record of Parastenocarididae from Thailand and description of a new genus (Copepoda: Harpacticoida). Journal of Crustacean Biology 30: 478-494. https://doi.org/10.1651/09-3201.1

Culver D.C. \& Sket B. 2000. Hotspots of subterranean biodiversity in caves and wells. Journal of Cave and Karst Sciences 62: 11-17.

Deharveng L. \& Bedos A. 2000. The cave fauna of Southeast Asia. Origin, evolution and ecology. In: Wilkens H., Culver D.C. \& Humphreys W.F. (eds) Subterranean Ecosystems: 603-633. Elsevier Academic Press, Amsterdam.

Deharveng L., Stoch F., Gibert J., Bedos A., Galassi D.M.P., Zagmajster M., Brancelj A., Camacho A.I., Fiers F., Martin P., Giani N., Magniez G. \& Marmonier P. 2009. Groundwater biodiversity in Europe. Freshwater Biology 54: 709-726. https://doi.org/10.1111/j.1365-2427.2008.01972.x

Dussart B.H. \& Defaye D. 2001. Introduction to the Copepoda, $2^{\text {nd }}$ edition. In: Dumont H.J.E. (ed.) Guides to the Identification of the Microinvertebrates of the Continental Waters of the World. Volume16: 1-344. Backhuys Publishers, Leiden.

Dussart B.H. \& Frutos S.M. 1986. Sur quelques copépodes d'Argentine. 2. Copépodes du Paraná Medio. Revue d'Hydrobiologie Tropicale 10: 241-262.

Fiers F. 2001. Meridiecyclops, gen. nov., a new cyclopid genus (Crustacea: Copepoda: Cyclopidae) from southern Australia. Invertebrate Taxonomy 15: 893-908.

https://doi.org/10.1071/IT01003\#sthash.7plNgFNg.dpuf

Fiers F. 2002. The genus Haplocyclops Kiefer, 1952 (Copepoda, Cyclopoida, Cyclopidae): Redescription of the type-species, H. gudrunae, and its congeners. Hydrobiologia 474: 155-169.

https://doi.org/10.1023/A:1016579619924

Galassi D.M.P. 2001. Groundwater copepods: diversity patterns over ecological and evolutionary scales. Hydrobiologia 453/454: 227-253. https://doi.org/10.1023/A:1013100924948

Galassi D.M.P. \& De Laurentiis T. 2004. Little-known cyclopoids from groundwater in Italy: revalidation of Acanthocyclops agamus and redescription of Speocyclops italicus (Crustacea, Copepoda, Cyclopoida). Vie et Milieu 54: 203-222.

Galassi D.P. \& Pesce G.L. 1992. The genus Hesperocyclops Herbst: an update, and description of Hesperocyclops venezuelanus n. sp. from Venezuela (Crustacea Copepoda: Cyclopidae). Stygologia 7: 219-224.

Galassi D.M.P., Huys R. \& Reid J.W. 2009. Diversity, ecology and evolution of groundwater copepods. Freshwater Biology 54: 691-708. https://doi.org/10.1111/j.1365-2427.2009.02185.x

Gibert J. \& Deharveng L. 2002. Subterranean ecosystems: A truncated functional biodiversity. BioScience 52: $473-481$.

Herbst H.V. 1984. Hesperocyclops improvisus n. g., n. sp., ein neuer Cyclopoide (Crustacea, Copepoda) von den westindischen Inseln. Bijdragen tot de Dierkunde 54: 66-72.

Hołyńska M., Reid J.W. \& Ueda H. 2003. Genus Mesocyclops Sars, 1914. In: Ueda H. \& Reid J.W. (eds) Copepoda: Cyclopoida. Genera Mesocyclops and Thermocyclops. Guides to the Identification of the Microinvertebrates of the Continental Waters of the World 20: 1-213. Backhuys Publishers, Leiden.

Huys R. \& Boxshall G.A. 1991. Copepod Evolution. The Ray Society, London.

Karanovic T. 2004. The genus Metacyclops Kiefer in Australia (Crustacea: Copepoda: Cyclopoida), with description of two new species. Records of the Western Australian Museum 22: 193-212. https://doi.org/10.18195/issn.0312-3162.22(3).2004.193-212 
BOONYANUSITH C. et al., New stygobiotic cyclopoid genus from Thailand

Karanovic T., Eberhard S.M. \& Murdoch A. 2011. A cladistic analysis and taxonomic revision of Australian Metacyclops and Goniocyclops, with description of four new species and three new genera (Copepoda, Cyclopoida). Crustaceana 84: 1-67. https://doi.org/10.1163/001121610X546698

Lim R.P. \& Fernando C.H. 1985. A review of Malaysian freshwater Copepoda with notes on new records and little known species. Hydrobiologia 128: 71-89. https://doi.org/10.1007/BF00008942

Lindberg K. 1947. Cyclopides (Crustacés Copépodes) nouveaux de l'Inde. I. Description des premiers Bryocyclops découverts dans l'Inde. Records of the Indian Museum 45: 47-55.

Lindberg K. 1956. Les Cyclopides (Crustacés Copépodes) très évolués en tant qu'habitants des eaux souterraines. Revue des travaux récents concernant les Bryocyclops Kiefer et Speocyclops Kiefer. Actes du Premier Congrès International de Spéléologie 3: 71-83.

Pandourski I. 1992.Contribution à l'étude des cyclopoides (Crustacea, Copepoda) des eaux souterraines karstiques de la Bulgarie avec description du Speocyclops rhodopensis sp. n. Acta Zoologica Bulgarica 45: 92-101.

Pesce G.L. 1985. Cyclopids (Crustacea, Copepoda) from West Indian groundwater habitats. Bijdragen tot de Dierkunde 55: 295-323.

Pesce G.L. 1996. Towards a revision of Cyclopinae copepods (Crustacea, Cyclopidae). Fragmenta Entomologica 28: 189-200.

Pesce G.L. \& Apostolov A.M. 1985. Elaphoidella margaritae sp. n., a new phreatobitic harpacticoid from subterranean waters of Thailand (Crustacea, Copepoda, Canthocamptidae). Acta Zoologica Bulgarica 28: 70-75.

Pipan T. \& Brancelj A. 2004. Distribution patterns of copepods (Crustacea: Copepoda) in percolation water of the Postojnska Jama Cave System (Slovenia). Zoological Studies 43: 206-210.

Pipan T., Christman M.C. \& Culver D.C. 2006. Dynamics of epikarst communities: microgeographic pattern and environmental determinants of epikarst copepods in Organ Cave, West Virginia. American Midland Naturalist 156: 75-87.

Reid J.W. 1991. The genus Metacyclops (Copepoda: Cyclopoida) present in North America: M. cushae, new species, from Louisiana. Journal of Crustacean Biology 11: 639-646.

https://doi.org/10.2307/1548532

Reid J.W. 1999. New records of Bryocyclops from the continental U.S.A., Puerto Rico, and Brazil (Copepoda: Cyclopoida: Cyclopidae). Journal of Crustacean Biology 19: 84-92.

https://doi.org/10.1163/193724099X00286

Reid J.W. \& Ishida T. 2000. Itocyclops, a new genus proposed for Speocyclops yesoensis (Copepoda: Cyclopoida: Cyclopidae). Journal of Crustacean Biology 20: 589-596.

Reid J.W., Strayer D.L., McArthur J.V., Stibbe S.E. \& Lewis J.J. 1999. Rheocyclops, a new genus of copepods from the southeastern and central U.S.A. (Copepoda: Cyclopoida: Cyclopidae). Journal of Crustacean Biology 19: 384-396. https://doi.org/10.2307/1549246

Rocha C.E.F. \& Carvalho Bjornberg M.H.G. 1987. Copepods of the Juréia Ecological Reserve, State of São Paulo, Brazil. II. The genera Hesperocyclops, Muscocyclops and Bryocyclops (Cyclopoida, Cyclopidae). Hydrobiologia 153: 97-107. https://doi.org/10.1007/BF00006642

Sanoamuang L. 1999. Species composition and distribution of freshwater Calanoida and Cyclopoida (Copepoda) of Northeast Thailand. In: Schram F.R. \& von Vaupel Klein J.C. (eds) Crustaceans and the Biodiversity Crisis. Proceeding of the Fourth International Crustacean Congress, 1998. Volume 1: 217-230. Brill, Leiden. 
Sket B. 1985. Why all cave animals do not look alike - a discussion on adaptive value of reduction processes. Journal of Cave and Karst Studies 47: 78-85.

Sket B. 1999. The nature of biodiversity in hypogean waters and how it is endangered. Biodiversity and Conservation 8: 1319-1338. https://doi.org/10.1023/A:1008916601121

Tran D.L. \& Hołyńska M. 2015. A new Mesocyclops with archaic morphology from a karstic cave in central Vietnam, and its implications for the basal relationships within the genus. Annales Zoologici (Warszawa) 65: 661-686. https://doi.org/10.3161/00034541ANZ2015.65.4.010

Walter T.C. 2015. Bryocyclops Kiefer, 1927. In: Walter T.C. \& Boxshall G. (eds) World of Copepods Database. Available from http://marinespecies.org/aphia.php?p=taxdetails\&id=346880 [accessed 13 Sep. 2017].

Watiroyram S., Brancelj A. \& Sanoamuang L. 2012. A new Bryocyclops Kiefer (Crustacea: Copepoda: Cyclopoida) from karstic caves in Thailand. The Raffles Bulletin of Zoology 60: 11-21.

Watiroyram S., Brancelj A. \& Sanoamuang L. 2015. A new cave-dwelling copepod from northeastern Thailand (Cyclopoida: Cyclopidae). The Raffles Bulletin of Zoology 63: 426-437.

White W.B. 2005. Hydrogeology of karst aquifers. In: Culver D.C. \& White W.B. (eds) Encyclopedia of Caves: 293-300. Elsevier Academic Press, Amsterdam.

Manuscript received: 3 July 2017

Manuscript accepted:14 December 2017

Published on: 3 May 2018

Topic editor: Rudy Jocqué

Desk editor: Kristiaan Hoedemakers

Printed versions of all papers are also deposited in the libraries of the institutes that are members of the EJT consortium: Muséum national d'Histoire naturelle, Paris, France; Botanic Garden Meise, Belgium; Royal Museum for Central Africa, Tervuren, Belgium; Natural History Museum, London, United Kingdom; Royal Belgian Institute of Natural Sciences, Brussels, Belgium; Natural History Museum of Denmark, Copenhagen, Denmark; Naturalis Biodiversity Center, Leiden, the Netherlands; Museo Nacional de Ciencias Naturales-CSIC, Madrid, Spain; Real Jardín Botánico de Madrid CSIC, Spain. 